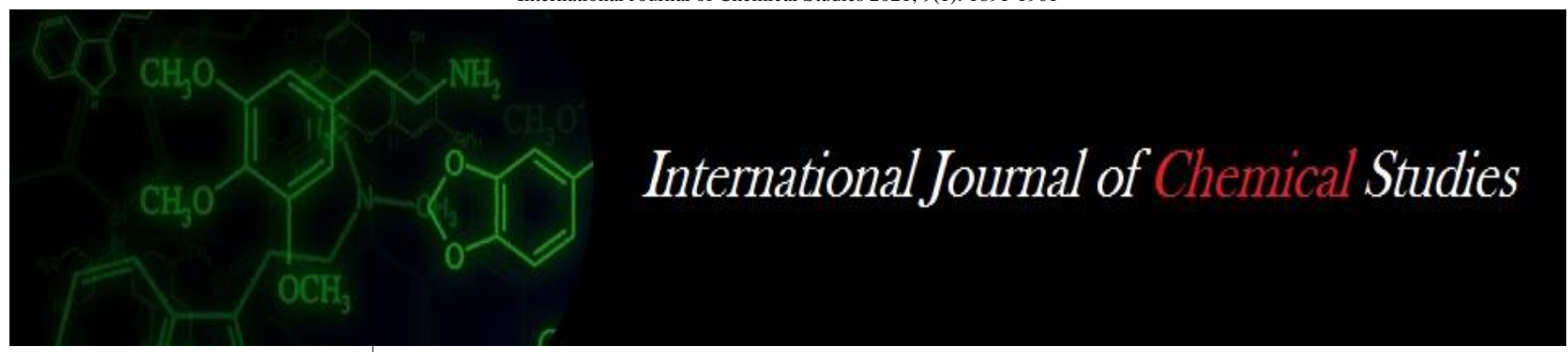

P-ISSN: 2349-8528

E-ISSN: 2321-4902

www.chemijournal.com

IJCS 2021; 9(1): 1891-1901

(C) 2021 IJCS

Received: 10-10-2020

Accepted: 21-11-2020

Samatha Timmareddygari College of Horticulture, Sri

Konda Laxman Telangana State

Horticultural University

(SKLTSHU), Rajendranagar,

Hyderabad, Telangana, India

\section{Saidaiah Pidigam}

College of Horticulture, Sri

Konda Laxman Telangana State

Horticultural University

(SKLTSHU), Rajendranagar,

Hyderabad, Telangana, India

Sivaraj Natarajan

ICAR-National Bureau of Plant

Genetic Resources,

Rajendranagar, Hyderabad,

Telangana, India

\section{Geetha Amarapalli}

Regional Agricultural Research

Station, PJTSAU, Palem,

Nagarkurnool, Telangana, India

Ravinder Reddy Komatireddy College of Horticulture, Sri

Konda Laxman Telangana State

Horticultural University

(SKLTSHU), Rajendranagar,

Hyderabad, Telangana, India

Corresponding Author:

Samatha Timmareddygari

College of Horticulture, Sri

Konda Laxman Telangana State

Horticultural University

(SKLTSHU), Rajendranagar,

Hyderabad, Telangana, India

\section{Estimation of heterosis for yield, yield attributes and quality parameters in brinjal (Solanum melongena $\mathrm{L}$.)}

\author{
Samatha Timmareddygari, Saidaiah Pidigam, Sivaraj Natarajan, Geetha \\ Amarapalli and Ravinder Reddy Komatireddy
}

DOI: https://doi.org/10.22271/chemi.2021.v9.i1aa.11498

\begin{abstract}
An investigation on three kinds of heterosis was taken up in twenty one single crosses along with ten parents and two standard checks (Arka Anand and Mahy Hari) at PG Students research farm, College of Horticulture, Rajendranagar, Hyderabad. Studies revealed that appreciable amount of heterobeltiosis and standard heterosis in desirable direction were recorded in a good number of crosses for majority of yield and yield contributing characters. The hybrids, RCBG-1 x Bhagyamathi for eleven characters viz., number of branches per plant, number of flower clusters per plant, number of fruits per plant, number of marketable fruits per plant, average fruit weight $(\mathrm{g})$, fruit yield per plant $(\mathrm{kg})$, marketable yield per plant $(\mathrm{kg})$, total yield per hectare(tons), total marketable yield per hectare(tons), ascorbic acid content $(\mathrm{mg} / 100 \mathrm{~g})$ and total phenols content $(\mathrm{mg} / 100 \mathrm{~g})$, RCBG-4 x Shyamala for number of flower clusters per plant, days to first flowering, days to $50 \%$ flowering, days to first harvest, number of marketable fruits per plant, average fruit weight $(\mathrm{g})$, fruit yield per plant $(\mathrm{kg})$, marketable yield per plant(kg), total yield per hectare(tons), total marketable yield per hectare(tons), and total phenols content(mg/100g), RCBG-2 x Bhagyamathi, RCBG-7 x Shyamala, RCBG-1 x Shyamala each for nine different yield and its contributing characters, were found superior and recorded significant standard heterosis and heterobeltiosis. The identified hybrids may be further tested over locations, seasons and years for commercial release for commercial cultivation.
\end{abstract}

Keywords: Estimation, heterosis, parameters, brinjal, Solanum melongena L.

\section{Introduction}

Egg plant or Brinjal (Solanum melongena L., $2 \mathrm{n}=2 \mathrm{x}=24$ ) belonging to the family Solanaceae, is one of the most commonly grown, important and popular vegetable crops in India. It is often referred as poor man's crop (Sharma et al., 2004) ${ }^{[47]}$, vegetable of masses (Patel and Sarnaik, 2003) ${ }^{[30]}$ and king of vegetables. The cultivated brinjal is of Indian origin. The region across India and Indo-china is considered the centre of diversity for brinjal (Vavilov, 1951) ${ }^{[58]}$.

India is major producer of brinjal in the world. In India, eggplant occupies an area of 0.73 million hectares with an annual production of 12.515 million tonnes and productivity stands at 18.9 MT/ha. The major brinjal growing states are West Benghal, Odisha, Gujarat, Madhya Pradesh, Bihar, Chhattisgarh, Andhra Pradesh, Maharashta, Karnataka and Telangana. In Telangana, it is grown over an area of 20,176 acres with a production of 2, 36,878 tonnes and productivity is $19.46 \mathrm{MT} / \mathrm{ha}$ (Dept. of Horticulture, Telangana, 2019-20). The unripe fruits of brinjal contain carbohydrate, protein, ascorbic acid, $\mathrm{Ca}, \mathrm{Mg}, \mathrm{Fe}, \mathrm{P}$, vitamin $\mathrm{B}_{6}$, niacin, pantothenic acid, vitamin A and vitamin $\mathrm{K}$. It is very low in calories and fats but rich in soluble fiber content. The peel has significant amounts of phenolic flavonoid phyto-chemicals called anthocyanins. They are also known to have alkaloid solanin in roots and leaves. Copper content, aminoacid content and polyphenol oxidase activity were highest in purple brinjal Where as $\mathrm{Fe}$, potassium and chloride content were highest in green cultivars.

Brinjal is grown for its immature, tender and unripe fruits which are used in variety of ways as cooked vegetable in curries. It has got much potential as raw material in pickle making and dehydration industries (Singh et al., 1963) ${ }^{[53]}$. The fruit is employed as cure for toothache. It has also been employed as excellent remedy for those suffering from liver complaints. 
Fruit is used as cardiotonic, laxative muturant and reliever of inflammation. White brinjals are good for diabetic patients (Singh et al., 1963) ${ }^{[53]}$. Other medicinal uses of brinjal include treatment of diabetes, asthma, cholera, bronchitis and dyspepsia. Fruits and leaves are administered to lower blood cholesterol levels.

The term Heterosis was coined by Shull (1914) ${ }^{[50]}$. Heterosis or average heterosis is measured as mean superiority of $F_{1}$ over the mid parent value, that is the average value of both the parents. The term Heterobeltiosis was proposed later to denote the expression of heterosis over better parent (Bitzer et al., 1968; Fonesca and Patterson, 1968) ${ }^{[7,7]}$. Since the better parent may fall on either of the extreme sides, heterobeltiosis may manifest in any of the two directions positive or negative. In some causes the superior parent may be inferior to the best commercial variety or hybrid. In such cases it is desirable to estimate heterosis in relation to the commercial variety. The superiority of $F_{1}$ over the standard commercial check is called as useful / standard / economic heterosis. The expression of heterosis may be due to factors such as heterozygosity, allelic interaction such as dominance or over dominance, non allelic interaction or epistasis and maternal interactions. The degree of expression of heterosis depends upon the number of genes in heterozygous condition. The higher the number of heterozygous alleles, the more is the heterosis expected (East and Hayes, 1912) ${ }^{[14]}$. Heterosis breeding is the most successful approach amongst various technological options available for the improvement in crop productivity (Saidaiah et al., 2008, 2012, Raghu et al., 2012) $[43,44,36]$. The phenomenon has extensively been exploited in cross pollinated as well as self pollinated crops.

In Brinjal, the earliest recorded instances of artificial hybridization were evidently carried out by Bailey and Munson in the United States in 1889, however, none of the hybrids exhibited heterosis but were intermediate between the parents (Bailey and Munson, 1892) ${ }^{[3]}$. Rao (1934) ${ }^{[40]}$ made the first report on hybridization of brinjal varieties in India and stated that the cross between two wide varieties, a high degree of partial sterility due to abortive pollen was observed. Venkataramani (1946) ${ }^{[59]}$ reported that the early parent and yielded more than either parent. In the same year, Pal and Singh (1946) ${ }^{[28]}$ reported that hybrid egg plants were taller, spread more and flowered earlier than the early parent had yielded more than either parent. In the same year, Pal and Singh reported that majority of the hybrids exhibited heterosis with respect to seed germination, plant height, plant spread, number of branches, early flowering, number of fruits per plant, fruit size and fruit yield. Heterosis breeding has become the widely used breeding method could enhance its quality and productivity without sacrificing the consumer's choice. Exploitation of hybrid vigour in brinjal is commercially possible (Bavage et al., 2005; Prabhu et al., 2005; Dharwad et al., 2011) ${ }^{[4,32,13]}$ and in other crops (Saidaiah et al., 2008, 2012, Raghu et al., 2012) ${ }^{[43,44,36]}$ due to manifestation of high heterosis and other important characters, ease of handling the flowers during artificial emasculation and pollination, and realization of high number of hybrid seed per effective pollination. The estimation of heterosis for yield and its component characters would therefore, useful to judge the best hybrid combination for exploitation of superior hybrids (Raghu et al., 2012) ${ }^{[36]}$. Keeping in view of the above discussed aspects, the present investigation was carried out with an objective of studying the heterosis of hybrids in field conditions.

\section{Material and Methods}

The seven genotypes viz., RCBG-1, RCBG-2, RCBG-3, RCBG-4, RCBG-5, RCBG-6 and RCBG-7 having high genetic divergence and desirable characters were selected as lines and three improved locally popular varieties viz., Bhagyamathi, Gulabi and Shyamala were selected as testers and were crossed in line $\mathrm{x}$ tester mating fashion during rabi, 2016. The resultant twenty one single crosses along with ten parents and two standard checks (Arka Anand and Mahy Hari) were evaluated in RBD following Panse and Sukatme, 1957 ANOVA for twenty yield and yield contributing traits at PG students research farm, College of Horticulture, Rajendranagar, Hyderabad in order to obtained information on the mean performance. Seeds of ten patents, twenty one hybrids and two commercial checks were sown on $25^{\text {th }}$ January, 2017 in plug trays and thirty two days old seedlings were transplanted in the main field. In each replication each genotype was grown in a plot of $1.8 \times 3.5 \mathrm{~m} 2$ consisting of three rows, accommodating 7 plants in each row. Row-torow spacing of $60 \mathrm{~cm}$ and plant-to-plant spacing of $50 \mathrm{~cm}$ was maintained. The recommended package of practices was followed to raise a successful crop and necessary prophylactic plant protection measures were carried out to safeguard the crop from pests and diseases. Heterosis is measured as mean superiority of $F_{1} s$ over their mid parent or better parent or the best commercial variety and thus, it is rated to be an important parameter in such studies. In the present investigation, all the three types of heterosis viz., relative heterosis, heterobeltiosis and standard heterosis (over Arka Anand/Mahy Hari) was estimated for twenty characters.

\section{Results and Discussion}

The analysis of variance of experimental material comprising 21 hybrids, 10 parents and 2 checks (Arka Anand and Mahy Hari) for twenty yield and yield contributing traits revealed that the replication mean sum of squares due to parents and hybrids were non significant for all the characters studied, which means there is no environmental error in controlling these characters. The treatment mean sum of squares due to parents and hybrids for all the characters under study were highly significant, indicating the presence of significant variation among the characters studied. The positive heterotic values are desirable for all the above characters except days to first flowering, days to $50 \%$ flowering and days to first harvest where negative heterosis indicates the earliness (Raghu et al., 2012) ${ }^{[36]}$.

High fruit yield in plants is manifested through enhancement in the vegetative characters like plant height and number of branches per plant hence positive heterosis was desirable for this trait. An average heterosis of -12.89 (RCBG-3 x Bhagyamathi) to 24.77 (RCBG-6 $\mathrm{x}$ Gulabi) and heterobeltiosis of -16.07 (RCBG-3 x Bhagyamathi) to 20.20 (RCBG-7 x Bhagyamathi) was registered for plant height. Out of 21 hybrids, fifteen and thirteen hybrids exhibited significant positive heterosis and heterobeltiosis respectively (Table 1). Heterosis range of -22.16 (RCBG-3 x Bhagyamathi) to 11.07 (RCBG-4 x Bhagyamathi) over Arka Anand and -14.56 (RCBG-3 x Bhagyamathi) to 21.92(RCBG7 x Bhagyamathi) over Mahy Hari was expressed for this trait. Significant positive standard heterosis was displayed by three hybrids viz., RCBG-4 x Bhagyamathi (11.07), RCBG-3 x Gulabi (10.76) and RCBG-7 x Gulabi (9.84) over Arka Anand and ten hybrids over Mahy Hari. These results are in close conformation with the findings of Prabhu et al. (2005) ${ }^{[32]}$, Ajjappalavara and Dharmatti (2006) ${ }^{[1]}$, Das et al. (2009) 
[11], Sao and Mehta (2011) ${ }^{[45]}$, Naresh et al. (2016) ${ }^{[26]}$, Palli et al. (2016) ${ }^{[29]}$, Patidar et al. (2017) ${ }^{[31]}$, Pramila et al. $(2017)^{[33]}$ and Kumar et al. (2017) ${ }^{[20]}$.

Number of branches per plant determines the fruit bearing surface and hence was considered as growth attribute. More number of branches per plant on the main stem, higher is the number of fruits per plant. Hence, positive heterosis is desirable for this character. The results are presented in Table 1. For number of branches per plant, heterosis range of -15.00 in RCBG-5 x Shyamala to 53.65 in RCBG-4 x Bhagyamathi over midparent and -18.19 in RCBG-5 x Shyamala to 50.55 in RCBG-4 x Bhagyamathi over better parent, with seven and six number of hybrids showing positive significant heterosis and heterobeltiosis respectively was observed. RCBG-4 $\mathrm{x}$ Bhagyamathi (50.69), RCBG-2 x Gulabi (43.69), RCBG-1 x Bhagyamathi (32.52), RCBG-6 x Gulabi (30.22) and RCBG-7 $\mathrm{x}$ Shyamala (27.80) were the five cross combinations which manifested significant positive standard heterosis over the check Mahy Hari and the range was varying from -23.60 (RCBG-5 x Shyamala) to 50.69(RCBG-4 x Bhagyamathi). Similar trends of results are also reported by Bavage (2002) ${ }^{[5]}$, Singh et al. (2004) [51], Prabhu et al. (2005) ${ }^{[32]}$, Gururaj et al. (2016) ${ }^{[17]}$, Gharge et al. (2016) ${ }^{[16]}$ and Pramila et al. $(2017)^{[33]}$.

The observed range of relative heterosis and heterobeltiosis for number of flower clusters per plant was -2.19 (RCBG-3 x Bhagyamathi) to 12.89 (RCBG-2 x Gulabi) and -6.52(RCBG$6 \mathrm{x}$ Bhagyamathi) to 10.48 (RCBG-2 x Gulabi) respectively. Twelve hybrids exhibited positive significant heterosis over midparent and eight hybrids over their respective better parent. As many as fifteen and twelve hybrids registered significant standard heterosis over Arka anand and Mahy Hari respectively. Heterosis range over Mahy Hari was varied between -1.99(RCBG-5 x Gulabi) to 17.98(RCBG-2 x Bhagyamathi). Sharma (2010) ${ }^{[49]}$ also reported similar results (Table 2).

With respect to number of flowers per cluster, seven and three were the number of hybrids recorded significant midparental heterosis and heterobeltiosis respectively. The extent of average heterosis was ranged from -23.63(RCBG-7 x Gulabi) to 79.77 (RCBG-1 x Shyamala) and heterobeltiosis was varied from $-42.56\left(\mathrm{RCBG}^{-7} \mathrm{x}\right.$ Gulabi) to 54.70(RCBG-1 $\mathrm{x}$ Shyamala) for number of flowers per cluster. Among 21 hybrids, only one hybrid, RCBG-4 x Gulabi expressed significant positive heterosis over standard check Mahy Hari and it was ranged from -55.61 in RCBG-7 $x$ Shyamala to 27.70 in RCBG-4 x Gulabi. Three hybrids shown significant positive heterosis over Arka Anand. These findings are in agreement with those of Singh and Maurya (2005) [52], Ajjappalavara and Dharmatti (2006) ${ }^{[1]}$, Shafeeq et al. (2007) ${ }^{[46]}$, Joshi et al. (2008) ${ }^{[18]}$ and Ramireddy et al. $(2011)^{[38]}$.

The results obtained in the present study pertaining to days to first flowering are given in Table 3, which revealed that a midparental heterosis range varying from -12.55 (RCBG-4 $\mathrm{x}$ Gulabi) to 15.55 (RCBG-2 x Shyamala) with eight hybrids exhibiting significant negative heterosis(desired) was observed for this character. As many as fourteen hybrids recorded significant negative and superior heterosis over their respective better parent, with a range of $-17.95(\mathrm{RCBG}-4 \mathrm{x}$ Shyamala) to 8.57 (RCBG-2 x Shyamala). When compared to Arka Anand, 7 hybrids showed significant negative heterosis and it was ranged between -15.04 in RCBG-4 x Shyamala to 3.54 in RCBG-6 x Bhagyamathi and RCBG-6 x Gulabi. The above results are in accordance with the earlier findings of Das and Barua (2001) ${ }^{[10]}$, Aswani and Khandelwal (2003) ${ }^{[2]}$,
Kumar and Pathania (2004) ${ }^{[22]}$, Sao and Mehta (2011) ${ }^{[45]}$ and Sharma et al. (2016) ${ }^{[48]}$.

Negative heterosis over mid parent, better parent and standard check is desirable for days to $50 \%$ flowering (Saidaiah et al., 2008, 2012, Raghu et al., 2012) ${ }^{[43,44,36]}$. Hybrids exhibited, relative heterosis having a range of -14.07 in RCBG-4 $\mathrm{x}$ Bhagyamathi to -0.39 in RCBG-5 x Gulabi for days to $50 \%$ flowering. None of the hybrids shown positive significant heterosis over both mid parent and better parent. Negative significant heterosis and heterobeltiosis was displayed by as many as fifteen and eighteen number of hybrids respectively. For this trait, heterosis over better parent was varied between -20.00 (RCBG-5 x Bhagyamathi) to -2.86 (RCBG-3 x Gulabi). The earliness attribute is one of the prime criterions in any crop improvement programme. The present study also brought out certain hybrids with significant earliness in days to first flowering. The four cross combinarions viz., RCBG-5 x Shyamala (-8.20), RCBG-5 x Bhagyamathi (-8.20), RCBG4 x Shyamala (-7.38), RCBG-1 x Shyamala (-7.38) were exhibited desired significant negative heterosis over the early flowering check Arka Anand (Table 3). Concurrent results are also reported by Bulgundi (2000) ${ }^{[8]}$, Kumar and Pathania (2004) ${ }^{[22]}$, Ajjappalavara and Dharmatti (2006) ${ }^{[1]}$, Das et al. (2009) [11], Chowdhary et al. (2010) [9], Ramireddy et al. (2011) ${ }^{[38]}$, Biswas et al. (2013) ${ }^{[6]}$, Sharma et al. (2016) ${ }^{[48],}$ Kumar et al. (2017) ${ }^{[20]}$ and Patidar et al. (2017) ${ }^{[31]}$.

Days to first fruit harvest is a measure of earliness, as early picking gives better returns and also widen the fruiting period of the plant. Hence, heterosis in negative direction is desirable for this trait. The results of three kinds of heterosis for days to first harvest are given in Table 4. With respect to this character, five hybrids recorded significant desired negative heterosis with a range of $-6.63(\mathrm{RCBG}-4 \mathrm{x}$ Gulabi) to 9.33(RCBG-2 x Shyamala) and heterobeltiosis was ranged from -13.83 in RCBG-7 $x$ Shyamala to 4.46 in RCBG-2 $x$ Shyamala with fifteen hybrids exhibiting earliness in harvest than their respective better parent. The magnitude of heterosis over standard check Arka Anand was varied from -11.45 to 4.22 and seven hybrids registered negative significant standard heterosis for days to first harvest. Similar results are also observed in the earlier studies conducted by Ashwani and khandelwal (2003) ${ }^{[2]}$, Chowdhary et al. (2010) ${ }^{[9]}$, Makani et al. (2013), Biswas et al. (2013) ${ }^{[6]}$, Sharma et al. (2016) ${ }^{[48],}$ Palli et al. (2016) ${ }^{[29]}$, Triveni et al., $2017^{[57]}$ and Patidar et al. $(2017)^{[31]}$.

In case of days to last harvest, the range of average heterosis and heterobeltiosis among hybrids was -4.88 (RCBG-5 $\mathrm{x}$ Gulabi) to 5.26(RCBG-2 x Shyamala) and -8.53(RCBG-5 x Gulabi) to 2.25(RCBG-4 x Bhagyamathi) respectively. Six hybrids were positively heterotic over midparent, while none of the hybrid shown significant positive heterosis over better parent (Table 4). Only two hybrids, RCBG-6 x Bhagyamathi (3.97) and RCBG-6 x Gulabi(3.75) manifested significant positive heterosis over best check Mahy Hari. The range of standard heterosis over Mahy Hari was -8.17 in RCBG-3 x Gulabi to 3.97 in RCBG-6 x Bhagyamathi.

Number of fruits per cluster is an important character for increasing the yielding ability in brinjal. More number of fruits per cluster means more number of long and medium styled flowers leads to more number of fruits per plant. Thus, positive heterosis was desirable for this trait and the results pertaining to this are presented in Table 5. Heterosis range varying from -42.59 in RCBG-5 x Gulabi to 75.75 in RCBG-1 $\mathrm{x}$ Shyamala was reported for number of fruits per cluster. For this character, heterobeltiosis was varied from -60.13(RCBG- 
$5 \mathrm{x}$ Gulabi) to 42.89 (RCBG-1 x Shyamala). Significant positive heterosis was displayed by four hybrids over mid parent and by only one hybrid RCBG-1 x Shyamala over respective better parent. Anologues kind of results are also reported by Singh and Maurya (2005) ${ }^{[52]}$, Shafeeq et al. (2007) ${ }^{[46]}$, Joshi et al. (2008) ${ }^{[18]}$ and Palli et al. (2016) ${ }^{[29]}$. Out of 21 hybrids, only one hybrid registered significant positive heterosis over the check Mahy Hari and three hybrids shown significant and positive heterosis over second best check Arka Anad. The economic heterosis over Mahy Hari and Arka Anand was varied from -56.08(RCBG-7 x Shyamala) to 19.73(RCBG-4 x Bhagyamathi) and 50.35(RCBG-7 $\mathrm{x}$ Shyamala) to 35.34(RCBG-4 $\mathrm{x}$ Bhagyamathi) respectively. These results are in conformity with earlier reports of Singh and Maurya (2005) ${ }^{[52]}$ and Magar et al. (2016) ${ }^{[23]}$.

Number of fruits per plant is of great significance for the improvement of fruit yield in brinjal. Hybrids were in the range of -16.58 in RCBG-5 x Gulabi to 40.49 in RCBG- $1 \times$ Bhagyamathi for relative heterosis and -19.77 RCBG-5 $x$ Gulabi in to 29.55 RCBG-1 $\mathrm{x}$ Bhagyamathi for heterobeltiosis. As many as fifteen and ten number of hybrids were positively and significantly heterotic over mid parent and better parent respectively. The above results are in consonance with the findings of Prabhu et al. (2005) ${ }^{[32]}$, Joshi et al. (2008) ${ }^{[18]}$, Ramireddy et al. (2011) ${ }^{[38]}$ and Magar et al. (2016) ${ }^{[23]}$ for average heterosis and Timmapur et al. (2008), Sharma (2010) [49] and Palli et al. (2016) [29] for heterobeltiosis. A standard heterosis range of -28.95 to 18.14 with three hybrids viz., RCBG-1 x Bhagyamathi (18.14), RCBG-4 $x$ Bhagyamathi (17.87) and RCBG-2 $x$ Bhagyamathi(13.56) showing significantly positive heterosis was reported for number of fruits per plant. Eight hybrids registered positive significant heterosis over next best check Arka Anand (Table 5). Similar trends of results are noticed by Sharma (2010) [49], Nalini et al. (2011), Ramireddy et al. (2011) [38], Dharwad et al. (2011) ${ }^{[13], ~ K u m a r ~ e t ~ a l . ~(2013) ~}{ }^{[21]}$ and Triveni et al., $2017^{[57]}$.

For number of marketable fruits per plant, heterosis range of 9.69 (RCBG-5 x Gulabi) to 55.45 (RCBG-1 x Bhagyamathi) over midparent and -18.95 in RCBG-5 x Gulabi to 36.38 in RCBG-1 x Bhagyamathi over better parent, with as many as sixteen and eleven number of hybrids showing positive significant heterosis and heterobeltiosis respectively was observed (Table 6). RCBG-1 x Bhagyamathi (24.01) and RCBG-4 x Shyamala (15.48) were the only two cross combinations which manifested significant positive standard heterosis over the check Mahy Hari and the range was varying from -31.34 (RCBG-5 $x$ Gulabi) to 24.01(RCBG-1 $x$ Bhagyamathi). The present findings are in agreement with earlier findings of Bavage et al. (2002) [5], Kumar and Pathania (2004) ${ }^{[22]}$, Joshi et al. (2008) ${ }^{[18]}$, Sharma (2010) ${ }^{[49]}$ Pachiyappan et al. (2012), Triveni et al., $2017^{[57]}$ and Pramila et al. (2017) ${ }^{[33]}$.

Fruit length is a growth attribute directly associated with yield, for which positive heterosis is desirable and the results obtained in the present study are given in Table 6 . An average heterosis of -22.41 (RCBG-7 x Gulabi) to 7.25 (RCBG-6 x Bhagyamathi) and heterobeltiosis of -33.48 (RCBG-6 $x$ Gulabi) to 7.18 (RCBG-6 x Bhagyamathi) was reported for fruit length. Out of 21 hybrids, none of the hybrid expressed significant positive heterosis and heterobeltiosis. Heterosis range of -53.25 (RCBG-5 x Shyamala) to -20.61 (RCBG-1 x Gulabi) over Arka Anand and -18.36 (RCBG-5 x Shyamala) to 38.61(RCBG-1 x Gulabi) over Mahy Hari was recorded for this trait. Significant positive standard heterosis was displayed by no hybrid over best check Arka Anand and by three hybrids viz., RCBG-1 x Gulabi, RCBG-3 x Gulabi and RCBG-4 x Gulabi over second best check Mahy Hari for fruit length, Timmapur et al. (2008), Das et al. (2009) ${ }^{[11]}$, Makani et al. (2013), Biswas et al. (2013) ${ }^{[6]}$, Magar et al. (2016) ${ }^{[23]}$ and Gharge et al. (2016) ${ }^{[16]}$ are also reported similar kind of results.

For fruit width $(\mathrm{cm})$, a midparental heterosis range varying from -17.76(RCBG-1 $\mathrm{x}$ Shyamala) to 13.43(RCBG-2 $\mathrm{x}$ Bhagyamathi) with only one hybrid exhibiting significant positive heterosis. None of the hybrid recorded significant positive and superior heterosis over better parent and range was varied from -26.65(RCBG-6 x Gulabi) to 11.92(RCBG-2 $\mathrm{x}$ Bhagyamathi) (Table 7). When compared to Arka Anand, 16 hybrids showed significant positive heterosis and it was ranged between 3.89 in RCBG-5 x Gulabi to 40.48 in RCBG6 x Shyamala. No hybrid was heterotic in performance over check Mahy Hari. The above findings are in close conformation with the earlier findings of Prathibha et al. (2004), Singh and Maurya (2005) ${ }^{[52]}$, Suneetha and Kathiria (2005), Ajjappalavara and Dharmatti (2006) ${ }^{[1]}$, Joshi et al. (2008) ${ }^{[18]}$, Chowdhury et al. (2010) ${ }^{[9]}$ and Pachiyappan et al. (2012)

Average fruit weight directly affects the total fruit yield, so this character is very important so far fruit yield is concerned. The results obtained in the present investigation for this character are presented in Table 7. Twelve and nine were the number of hybrids recorded significant midparental heterosis and heterobeltiosis respectively. Average heterosis was ranged from -15.18 (RCBG-6 $\mathrm{x}$ Bhagyamathi) to 26.67(RCBG-7 x Shyamala) and heterobeltiosis was varied from -22.63(RCBG-6 x Bhagyamathi) to 25.95 (RCBG-7 x Shyamala) for average fruit weight. Singh et al. (2004) ${ }^{[51]}$, Suneetha and kathiria (2005), Nalini et al. (2011), Ramireddy et al. (2011) ${ }^{[38]}$, Biswas et al. (2013) ${ }^{[6]}$, Sharma et al. (2016) ${ }^{[48]}$ and Palli et al. (2016) ${ }^{[29]}$ are also reported similar trends of results. Among 21 hybrids, eight hybrids expressed significant and positive heterosis over standard check Mahy Hari and it was ranged from -8.93 in RCBG-6 x Bhagyamathi to 23.51 in RCBG-1 x Bhagyamathi. Nine hybrids shown significant positive heterosis over second best check Arka Anand. These findings are in accordance with the earlier reports of Nalini et al. (2011), Reddy and Patel (2014), Gharge et al. (2016) ${ }^{[16]}$, Triveni et al., $2017^{[57]}$ and Kumar et al. $(2017)^{[20]}$.

With respect to fruit yield per plant $(\mathrm{kg})$, hybrids were in the range of -22.08 in RCBG-7 $x$ Bhagyamathi to 91.87 in RCBG-7 x Shyamala for average heterosis and -28.74 in RCBG-7 x Bhagyamathi to 87.82 in RCBG-7 x Shyamala for heterobeltiosis. As many as sixteen and thirteen number of hybrids was positively and significantly heterotic over mid parent and better parent respectively. An economic heterosis range of -40.81 to 39.84 with six hybrids viz., RCBG-2 $\mathrm{x}$ Bhagyamathi(39.84), RCBG-4 x Shyamala(36.94), RCBG-1 x Bhagyamathi(30.97), RCBG-7 x Shyamala(29.35), RCBG-1 x Shyamala(25.32) and RCBG-3 x Bhagyamathi(22.10) showing significantly positive heterosis was reported for number of fruits per plant. Eight hybrids, RCBG-2 x Bhagyamathi (54.82), RCBG-4 x Shyamala (51.61), RCBG-1 x Bhagyamathi (45.00), RCBG-7 x Shyamala (43.21), RCBG1 x Shyamala (38.75), RCBG-3 x Bhagyamathi (35.18), RCBG-6 x Shyamala (30.89) and RCBG-2 x Gulabi (31.79) registered positive significant heterosis over next best check Arka Anand (Table 8). These results are in close conformity 
with the earlier findings of Shafeeq et al. (2007) ${ }^{[46]}$, Sharma et al. (2010) ${ }^{[49]}$, Sao and Mehta (2011) ${ }^{[45]}$, Pachiyappan et al. (2012), Makani et al. (2013), Biswas et al. (2013) ${ }^{[6]}$, Gharge et al. (2016) ${ }^{[16]}$, Gururaj et al. (2016) ${ }^{[17]}$, Palli et al. (2016) ${ }^{[29]}$, Pramila et al. (2017) ${ }^{[33]}$ and Rani et al. (2018).

The wide range of relative heterosis and heterobeltiosis for marketable fruit yield per plant -20.60(RCBG-7 x Bhagyamathi) to 141.93(RCBG-7 $\mathrm{x}$ Shyamala) and 28.51(RCBG-7 x Bhagyamathi) to 105.71 (RCBG-7 $\mathrm{x}$ Shyamala) was observed respectively. As many as sixteen hybrids exhibited positive significant heterosis over midparent and also over respective better parent. From the Table 8 , it was observed that among 21 hybrids, ten hybrids viz., RCBG4 x Shyamala (58.72), RCBG-2 x Bhagyamathi (54.83), RCBG-1 x Bhagyamathi (53.06), RCBG-7 x Shyamala (41.12), RCBG-1 x Shyamala (40.87), RCBG-2 x Gulabi (35.06), RCBG-6 x Shyamala (33.68), RCBG-3 x Bhagyamathi (32.60), RCBG-3 x Shyamala (31.32) and RCBG-4 x Gulabi (26.36) and six hybrids, RCBG-4 x Shyamala (44.19), RCBG-2 x Bhagyamathi (40.65), RCBG-1 x Bhagyamathi (39.05), RCBG-7 x Shyamala (28.20), RCBG1 x Shyamala (27.98) and RCBG-2 x Gulabi (22.69) registered significant standard heterosis over Arka Anand and Mahy Hari respectively. Heterosis range over Mahy Hari was varied between $-44.37(\mathrm{RCBG}-7 \mathrm{x}$ Bhagyamathi) to 44.19(RCBG-4 x Shyamala). The present results are in concurrent with the findings of Prabhu et al. (2005) [32], Suneetha and Kathiria (2006), Shafeeq et al. (2007) ${ }^{[46]}$, Joshi et al. (2008) ${ }^{[18]}$, Chowdhury et al. (2010) ${ }^{[9]}$, Sharma (2010) ${ }^{\text {[49] }}$, Sao and Mehta (2011) ${ }^{[45]}$, Praneetha et al. (2013) and Kumar et al. (2013) ${ }^{[21]}$.

Heterosis range varying from -22.09 in RCBG-7 $x$ Bhagyamathi to 91.87 in RCBG-7 x Shyamala was reported for fruit yield per hectare. For this character, heterobeltiosis was varied from -28.75 (RCBG-7 $x$ Bhagyamathi) to 87.84(RCBG-7 x Shyamala). Significant positive heterosis was displayed by sixteen hybrids over mid parent and by thirteen hybrids over respective better parent (Table 9). Out of 21 hybrids, six hybrids registered significant positive heterosis over the check Mahy Hari and nine hybrids shown significant and positive heterosis over second best check Arka Anand. The economic heterosis over Mahy Hari and Arka Anand was varied from -40.82 (RCBG-7 x Bhagyamathi) to 39.83(RCBG-2 x Bhagyamathi) and -34.48 in RCBG-7 $x$ Bhagyamathi to 54.81 in RCBG-2 $x$ Bhagyamathi respectively. Similar results are also noticed by Joshi et al. (2008) ${ }^{[18]}$, Magar et al. (2016) ${ }^{[23]}$, Pramila et al. (2017) ${ }^{[33]}$ and Rani et al. (2018).

For total marketable yield per hectare (tons), the observed range of average heterosis and heterobeltiosis among hybrids was -20.61(RCBG-7 x Bhagyamathi) to 145.97(RCBG-4 x Shyamala) and $-28.51(\mathrm{RCBG}-7 \mathrm{x}$ Bhagyamathi) to 105.70(RCBG-7 x Shyamala) respectively. As many as sixteen hybrids were positively heterotic over midparent and over respective better parent. Six hybrids viz., RCBG-4 x Shyamala(44.18), RCBG-2 x Bhagyamathi (40.65), RCBG-1 x Bhagyamathi(39.04), RCBG-7 x Shyamala(28.20), RCBG-1 x Shyamala(27.97) and RCBG-2 x Gulabi(22.69) manifested significant positive heterosis over best check Mahy Hari. The range of standard heterosis over Mahy Hari was -44.38 in RCBG-7 x Bhagyamathi to 44.18 in RCBG-4 x Shyamala.

With respect to the ascorbic acid content, sixteen hybrids recorded significant positive heterosis with a range of 13.93(RCBG-6 x Gulabi) to 38.97(RCBG-4 x Gulabi) and heterobeltiosis was ranged from -20.93 in RCBG-6 x Gulabi to 36.17 in RCBG-4 x Gulabi with thirteen hybrids exhibiting significant and positive heterosis over respective better parent (Table 10). Heterosis over standard check Mahy Hari was varied from -34.35(RCBG-6 x Shyamala) to 20.77(RCBG-1 x Bhagyamathi) and four hybrids viz., RCBG-1 x Bhagyamathi (20.77), RCBG-4 x Gulabi (15.87), RCBG-2 x Gulabi (10.10) and RCBG-1 x Gulabi(5.60) registered positive significant standard heterosis for this character. Earlier reports of Kanthaswamy et al. (2003) and Rani et al. (2018) are in proportionate with the above results.

Hybrids exhibited, relative heterosis having a range of 4.80 in RCBG-6 x Gulabi to 53.74 in RCBG-1 x Shyamala for total phenols content $(\mathrm{mg} / 100 \mathrm{~g})$. None of the hybrid shown desirable negative significant heterosis over mid parent and only four hybrids was negatively significant over better parent. For this trait, heterosis over better parent was varied between -12.32(RCBG-3 x Bhagyamathi) to 47.54(RCBG-1 x Shyamala). None of the hybrid exhibited desirable significant negative heterosis over both the checks (Table 10). Anologues kind of earlier findings are noticed by Suneetha et al. (2005) and Patidar et al. (2017) ${ }^{[31]}$. Marketable yield is the resultant manifest of its component traits, and heterosis observed for them contributes ultimately towards this complex character. The highest relative heterosis, heterobeltiosis were exhibited by crosses RCBG-7 x Shyamala, RCBG-3 x Shyamala, RCBG-4 x Shyamala, RCBG-1 x Shyamala, RCBG-2 x Bhagyamathi, RCBG-6 x Shyamala, RCBG-1 x Bhagyamathi, RCBG-2 x Gulabi, RCBG-2 x Shyamala, RCBG-4 x Gulabi, RCBG-3 x Bhagyamathi, RCBG-7 x Gulabi, RCBG-1 $x$ Gulabi and standard heterosis by the crosses RCBG-4 $\mathrm{x}$ Shyamala, RCBG-2 x Bhagyamathi, RCBG-1 x Bhagyamathi, RCBG-7 x Shyamala, RCBG-1 x Shyamala, RCBG-2 x Gulabi for marketable yield per plant (Table 8). From study, it was concluding that the cross combinations RCBG- $1 \mathrm{x}$ Bhagyamathi, RCBG-4 x Shyamala, RCBG-2 x Bhagyamathi, RCBG-7 $x$ Shyamala and RCBG-1 x Shyamala were identified as top standard heterotic crosses for marketable fruit yield per plant and its contributing characters. The identified hybrids may be further tested over locations, seasons and years for commercial release for commercial cultivation.

Table 1: Average heterosis (\%), heterobeltiosis $(\%)$ and standard heterosis $(\%)$ for plant height $(\mathrm{cm})$ and number of branches in brinjal

\begin{tabular}{|c|c|c|c|c|c|c|c|c|}
\hline \multirow{3}{*}{ Crosses } & \multicolumn{4}{|c|}{ Plant height (cm) } & \multicolumn{4}{|c|}{ Number of branches per plant } \\
\hline & \multirow{2}{*}{$\begin{array}{c}\text { Average } \\
\text { heterosis } \\
(\%)\end{array}$} & \multirow{2}{*}{$\begin{array}{c}\text { Heterobeltiosis } \\
(\%)\end{array}$} & \multicolumn{2}{|c|}{ Standard heterosis (\%) } & \multirow{2}{*}{$\begin{array}{c}\text { Average } \\
\text { heterosis } \\
(\%)\end{array}$} & \multirow{2}{*}{$\begin{array}{c}\text { Heterobeltiosis } \\
(\%)\end{array}$} & \multicolumn{2}{|c|}{ Standard heterosis (\%) } \\
\hline & & & Arka Anand & $\begin{array}{l}\text { Mahy } \\
\text { Hari }\end{array}$ & & & Arka Anand & $\begin{array}{c}\text { Mahy } \\
\text { Hari }\end{array}$ \\
\hline RCBG-1 x Bhagyamathi & $8.74 * *$ & 3.43 & -1.45 & $8.17 *$ & $39.31 * *$ & $37.95 * *$ & $55.34 * *$ & $32.52 * *$ \\
\hline RCBG-1 x Gulabi & $-7.18 *$ & $-8.09 *$ & $-10.68 * *$ & -1.96 & 2.74 & 0.99 & 11.51 & -4.88 \\
\hline RCBG-1 x Shyamala & $18.27 * *$ & $8.13 *$ & 3.03 & $13.08 * *$ & 16.81 & 11.96 & 23.62 & 5.46 \\
\hline RCBG-2 x Bhagyamathi & -1.77 & -2.49 & $-14.93 * *$ & -6.62 & $25.49 *$ & $24.97 *$ & $41.90 * *$ & 21.05 \\
\hline RCBG-2 x Gulabi & $10.74 * *$ & 5.08 & 2.12 & $12.09 * *$ & $52.97 * *$ & $48.33 * *$ & $68.43 * *$ & $43.69 * *$ \\
\hline RCBG-2 x Shyamala & $13.43 * *$ & $8.03^{*}$ & -5.74 & 3.46 & 16.26 & 9.97 & 24.87 & 6.52 \\
\hline
\end{tabular}




\begin{tabular}{|c|c|c|c|c|c|c|c|c|}
\hline RCBG-3 x Bhagyamathi & $-12.89 * *$ & $-16.07 * *$ & $-22.16 * *$ & $-14.56 * *$ & -5.98 & -5.98 & 5.87 & -9.69 \\
\hline RCBG-3 x Gulabi & $16.63 * *$ & $13.97 * *$ & $10.76^{* *}$ & $21.57 * *$ & 7.72 & 4.87 & 18.09 & 0.74 \\
\hline RCBG-3 x Shyamala & 5.32 & -2.52 & $-9.59 * *$ & -0.76 & 0.92 & -4.17 & 7.91 & -7.94 \\
\hline RCBG-4 x Bhagyamathi & $21.91 * *$ & $15.40 * *$ & $11.07 * *$ & $21.92 * *$ & $53.65 * *$ & $50.55 * *$ & $76.65 * *$ & $50.69 * *$ \\
\hline RCBG-4 x Gulabi & $9.55 * *$ & $9.02 *$ & 5.95 & $16.30 * *$ & 17.13 & 11.81 & $31.19 *$ & 11.91 \\
\hline RCBG-4 x Shyamala & 2.03 & $-7.14 *$ & $-10.62 * *$ & -1.90 & -5.04 & -11.55 & 3.79 & -11.46 \\
\hline RCBG-5 x Bhagyamathi & $15.91 * *$ & $12.74 * *$ & -3.08 & 6.39 & 1.24 & -0.17 & 12.41 & -4.10 \\
\hline RCBG-5 x Gulabi & $19.01 * *$ & $9.26^{*}$ & 6.18 & $16.55 * *$ & $30.75 * *$ & $29.08 *$ & $41.29 * *$ & 20.54 \\
\hline RCBG-5 x Shyamala & 3.47 & 1.99 & $-17.12 * *$ & $-9.30 *$ & -15.00 & -18.19 & -10.45 & -23.60 \\
\hline RCBG-6 x Bhagyamathi & $17.70 * *$ & $8.60 *$ & -6.64 & 2.48 & -6.34 & -12.61 & -1.59 & -16.05 \\
\hline RCBG-6 x Gulabi & $24.77 * *$ & $9.04 *$ & 5.97 & $16.31 * *$ & $49.51 * *$ & $43.12 * *$ & $52.65 * *$ & $30.22 *$ \\
\hline RCBG-6 x Shyamala & $23.83 * *$ & $18.92 * *$ & -6.12 & 3.04 & 2.63 & 0.75 & 2.01 & -12.98 \\
\hline RCBG-7 x Bhagyamathi & $21.91 * *$ & $20.20 * *$ & 3.33 & $13.42 * *$ & -5.38 & -12.77 & 16.39 & -0.71 \\
\hline RCBG-7 x Gulabi & $21.55 * *$ & $13.02 * *$ & $9.84 * *$ & $20.56 * *$ & -3.80 & -13.45 & 15.48 & -1.49 \\
\hline RCBG-7 x Shyamala & $21.09 * *$ & $17.76 * *$ & -1.62 & $7.99 *$ & $27.68 * *$ & 12.28 & $49.81 * *$ & $27.80 *$ \\
\hline
\end{tabular}

$* *$ Significant at $1 \%$ level and * Significant at $5 \%$ level

Table 2: Average heterosis (\%), heterobeltiosis (\%) and standard heterosis (\%) for number of flower clusters per plant and number of flowers per cluster in brinjal

\begin{tabular}{|c|c|c|c|c|c|c|c|c|}
\hline \multirow{3}{*}{ Crosses } & \multicolumn{4}{|c|}{ Number of flower clusters per plant } & \multicolumn{4}{|c|}{ Number of flowers per cluster } \\
\hline & \multirow{2}{*}{$\begin{array}{c}\text { Average } \\
\text { heterosis (\%) }\end{array}$} & \multirow{2}{*}{\begin{tabular}{|c|} 
Heterobeltiosis \\
$(\%)$
\end{tabular}} & \multicolumn{2}{|c|}{ Standard heterosis (\%) } & \multirow{2}{*}{\begin{tabular}{|c|} 
Average \\
heterosis \\
$(\%)$
\end{tabular}} & \multirow{2}{*}{$\begin{array}{c}\text { Heterobeltiosis } \\
(\%)\end{array}$} & \multicolumn{2}{|c|}{ Standard heterosis (\%) } \\
\hline & & & $\begin{array}{c}\text { Arka } \\
\text { Anand }\end{array}$ & Mahy Hari & & & Arka Anand & $\begin{array}{l}\text { Mahy } \\
\text { Hari }\end{array}$ \\
\hline RCBG-1 x Bhagyamathi & $12.69 * *$ & $6.83 *$ & $17.83 * *$ & $14.32 * *$ & $18.68 * *$ & -4.84 & 7.68 & 5.36 \\
\hline RCBG-1 x Gulabi & $10.32 * *$ & $8.70 *$ & $10.67 * *$ & $7.38 *$ & -2.25 & $-20.65^{*}$ & -13.05 & -14.93 \\
\hline RCBG-1 x Shyamala & $9.43 * *$ & 4.90 & $13.03 * *$ & $9.67 * *$ & $79.77 * *$ & $54.70 * *$ & 5.68 & 3.40 \\
\hline RCBG-2 x Bhagyamathi & $12.25 * *$ & $10.25 * *$ & $21.60 * *$ & $17.98 * *$ & 4.04 & -2.98 & 9.79 & 7.42 \\
\hline RCBG-2 x Gulabi & $12.89 * *$ & $10.48 * *$ & $17.50 * *$ & $14.01 * *$ & 3.60 & -1.92 & 7.47 & 5.15 \\
\hline RCBG-2 x Shyamala & 2.75 & 2.08 & $10.00 * *$ & 6.73 & $57.51 * *$ & 18.39 & 15.89 & 13.39 \\
\hline RCBG-3 x Bhagyamathi & -2.19 & -5.75 & 3.96 & 0.86 & $39.74 * *$ & 6.14 & $20.11 * *$ & 17.51 \\
\hline RCBG-3 x Gulabi & 4.05 & 3.82 & 6.18 & 3.02 & -12.57 & $-32.85 * *$ & $-26.42 * *$ & $-28.01 * *$ \\
\hline RCBG-3 x Shyamala & 0.78 & -1.78 & 5.84 & 2.69 & 5.07 & -3.41 & $-43.26 * *$ & $-44.49 * *$ \\
\hline RCBG-4 x Bhagyamathi & -1.31 & -2.64 & $7.38 *$ & 4.19 & $30.70 * *$ & 6.33 & $20.32 *$ & 17.71 \\
\hline RCBG-4 x Gulabi & $9.57 * *$ & $6.77 *$ & $14.57 * *$ & $11.17 * *$ & $44.61 * *$ & $19.12^{*}$ & $30.53 * *$ & $27.70 * *$ \\
\hline RCBG-4 x Shyamala & $9.57 * *$ & $9.35 * *$ & $17.83 * *$ & $14.32 * *$ & $67.60 * *$ & $41.99 * *$ & 0.74 & -1.44 \\
\hline RCBG-5 x Bhagyamathi & $9.16^{* *}$ & 4.07 & $14.78 * *$ & $11.37 * *$ & -5.55 & $-17.67 *$ & -6.84 & -8.86 \\
\hline RCBG-5 x Gulabi & 0.10 & -0.79 & 1.01 & -1.99 & 0.76 & -10.95 & -2.42 & -4.53 \\
\hline RCBG-5 x Shyamala & $11.17 * *$ & $7.17 *$ & $15.48 * *$ & $12.05 * *$ & 0.24 & -20.53 & $-33.16 * *$ & $-34.60 * *$ \\
\hline RCBG-6 x Bhagyamathi & -0.52 & -6.52 & 3.10 & 0.03 & $-18.35^{*}$ & $-35.63 * *$ & $-27.16 * *$ & $-28.73 * *$ \\
\hline RCBG-6 x Gulabi & 5.19 & 2.69 & 4.56 & 1.45 & $-22.46^{*}$ & $-38.14 * *$ & $-32.21 * *$ & $-33.68 * *$ \\
\hline RCBG-6 x Shyamala & $9.58 * *$ & 4.10 & $12.18 * *$ & $8.84 *$ & 8.09 & -5.16 & $-38.11 * *$ & $-39.44 * *$ \\
\hline RCBG-7 x Bhagyamathi & 3.18 & -0.02 & $10.28 * *$ & 7.00 & 3.62 & $-22.88 * *$ & -12.74 & -14.62 \\
\hline RCBG-7 x Gulabi & $10.63^{* *}$ & $9.75 * *$ & $13.55^{* *}$ & $10.17 * *$ & $-23.63^{*}$ & $-42.56^{* *}$ & $-37.05 * *$ & $-38.41 * *$ \\
\hline RCBG-7 x Shyamala & $6.28 *$ & 4.16 & $12.25 * *$ & $8.91 *$ & -13.19 & -17.90 & $-54.63 * *$ & $-55.61 * *$ \\
\hline
\end{tabular}

** Significant at $1 \%$ level and * Significant at $5 \%$ level

Table 3: Average heterosis (\%), heterobeltiosis (\%) and standard heterosis (\%) for days to first flowering and days to $50 \%$ flowering in brinjal

\begin{tabular}{|c|c|c|c|c|c|c|c|c|}
\hline \multirow{3}{*}{ Crosses } & \multicolumn{4}{|c|}{ Days to first flowering } & \multicolumn{4}{|c|}{ Days to 50\% flowering } \\
\hline & \multirow{2}{*}{$\begin{array}{c}\text { Average } \\
\text { heterosis } \\
(\%)\end{array}$} & \multirow[b]{2}{*}{$\begin{array}{c}\text { Heterobeltiosis } \\
(\%)\end{array}$} & \multicolumn{2}{|c|}{ Standard heterosis (\%) } & \multirow{2}{*}{$\begin{array}{c}\text { Average } \\
\text { heterosis } \\
(\%)\end{array}$} & \multirow{2}{*}{$\begin{array}{c}\text { Heterobeltiosis } \\
(\%)\end{array}$} & \multicolumn{2}{|c|}{ Standard heterosis (\%) } \\
\hline & & & Arka Anand & Mahy Hari & & & Arka Anand & $\begin{array}{l}\text { Mahy } \\
\text { Hari }\end{array}$ \\
\hline RCBG-1 x Bhagyamathi & $-8.77 * *$ & $-9.57 *$ & $-7.69 *$ & $-13.33 * *$ & $-13.97 * *$ & $-16.43 * *$ & -4.10 & $-11.36^{* *}$ \\
\hline RCBG-1 x Gulabi & $-7.76^{*}$ & $-13.08 * *$ & 0.00 & -5.83 & $-6.62 * *$ & $-9.29 * *$ & 4.10 & -3.79 \\
\hline RCBG-1 x Shyamala & -0.96 & $-10.43 * *$ & $-8.85 *$ & $-14.17 * *$ & $-8.13 * *$ & $-14.39 * *$ & $-7.38 *$ & $-14.39 * *$ \\
\hline RCBG-2 x Bhagyamathi & -3.67 & -7.08 & -7.08 & $-12.50 * *$ & $-8.68 * *$ & $-13.57 * *$ & -0.82 & $-8.33 * *$ \\
\hline RCBG-2 x Gulabi & -3.83 & $-13.08 * *$ & 0.00 & -5.83 & $-6.42 * *$ & $-11.43 * *$ & 1.64 & $-6.06^{*}$ \\
\hline RCBG-2 x Shyamala & $15.15 * *$ & $8.57 *$ & 0.88 & -5.00 & -1.26 & -5.60 & -3.28 & $-10.61 * *$ \\
\hline RCBG-3 x Bhagyamathi & 2.22 & 1.77 & 1.77 & -4.17 & -4.35 & $-5.71 *$ & $8.20 * *$ & 0.00 \\
\hline RCBG-3 x Gulabi & $-9.09^{* * *}$ & $-15.38 * *$ & -2.65 & $-8.33^{*}$ & -1.45 & -2.86 & $11.48^{* *}$ & 3.03 \\
\hline RCBG-3 x Shyamala & -4.39 & $-12.50 * *$ & $-13.27 * *$ & $-18.33 * *$ & $-8.00 * *$ & $-15.44 * *$ & -5.74 & $-12.88 * *$ \\
\hline RCBG-4 x Bhagyamathi & $-7.83^{*}$ & $-9.40 *$ & -6.19 & $-11.67 * *$ & $-14.07 * *$ & $-17.44 * *$ & -4.92 & $-12.12 * *$ \\
\hline RCBG-4 x Gulabi & $-12.55 * *$ & $-16.92 * *$ & -4.42 & $-10.00 * *$ & $-11.11 * *$ & $-14.29 * *$ & -1.64 & $-9.09 * *$ \\
\hline RCBG-4 x Shyamala & $-8.57 *$ & $-17.95 * *$ & $-15.04 * *$ & $-20.00 * *$ & $-7.38 * *$ & $-13.08 * *$ & $-7.38 *$ & $-14.39 * *$ \\
\hline RCBG-5 x Bhagyamathi & $-10.50 * *$ & $-13.27 * *$ & $-13.27 * *$ & $-18.33 * *$ & $-12.84 * *$ & $-20.00 * *$ & $-8.20 * *$ & $-15.15^{* *}$ \\
\hline RCBG-5 x Gulabi & -4.24 & $-13.08 * *$ & 0.00 & -5.83 & -0.39 & $-8.57 * *$ & 4.92 & -3.03 \\
\hline RCBG-5 x Shyamala & -2.51 & $-8.49 *$ & $-14.16 * *$ & $-19.17 * *$ & -3.03 & -4.27 & $-8.20 * *$ & $-15.15 * *$ \\
\hline RCBG-6 x Bhagyamathi & -5.26 & $-12.69 * *$ & 3.54 & -2.50 & $-7.42 * *$ & $-8.39 * *$ & $7.38 *$ & -0.76 \\
\hline RCBG-6 x Gulabi & $-11.36 * *$ & $-12.69 * *$ & 3.54 & -2.50 & $-8.83 * *$ & $-9.79 * *$ & 5.74 & -2.27 \\
\hline
\end{tabular}




\begin{tabular}{|c|c|c|c|c|c|c|c|c|}
\hline RCBG-6 x Shyamala & $-6.61^{*}$ & $-20.90^{* *}$ & -6.19 & $-11.67^{* *}$ & $-5.84^{*}$ & $-15.38^{* *}$ & -0.82 & $-8.33^{* *}$ \\
\hline RCBG-7 x Bhagyamathi & 2.68 & 1.77 & 1.77 & -4.17 & $-5.26^{*}$ & $-10.00^{* *}$ & 3.28 & -4.55 \\
\hline RCBG-7 x Gulabi & $-8.71^{* *}$ & $-15.38^{* *}$ & -2.65 & $-8.33^{*}$ & $-6.77^{* *}$ & $-11.43^{* *}$ & 1.64 & $-6.06^{*}$ \\
\hline RCBG-7 x Shyamala & -1.96 & $-9.91^{*}$ & $-11.50^{* *}$ & $-16.67 * *$ & -4.17 & $-8.73^{* *}$ & -5.74 & $-12.88^{* *}$ \\
\hline
\end{tabular}

** Significant at $1 \%$ level and * Significant at $5 \%$ level

Table 4: Average heterosis (\%), heterobeltiosis (\%) and standard heterosis (\%) for days to first harvest and days to last harvest in brinjal

\begin{tabular}{|c|c|c|c|c|c|c|c|c|}
\hline \multirow{3}{*}{ Crosses } & \multicolumn{4}{|c|}{ Days to first harvest } & \multicolumn{4}{|c|}{ Days to last harvest } \\
\hline & \multirow{2}{*}{$\begin{array}{c}\text { Average } \\
\text { heterosis }(\%)\end{array}$} & \multirow{2}{*}{$\begin{array}{c}\text { Heterobeltiosis } \\
(\%)\end{array}$} & \multicolumn{2}{|c|}{ Standard heterosis (\%) } & \multirow{2}{*}{$\begin{array}{c}\text { Average } \\
\text { heterosis } \\
(\%)\end{array}$} & \multirow{2}{*}{\begin{tabular}{|c|} 
Heterobeltiosis \\
$(\%)$
\end{tabular}} & \multicolumn{2}{|c|}{ Standard heterosis (\%) } \\
\hline & & & Arka Anand & $\begin{array}{c}\text { Mahy } \\
\text { Hari }\end{array}$ & & & Arka Anand & $\begin{array}{c}\text { Mahy } \\
\text { Hari }\end{array}$ \\
\hline RCBG-1 x Bhagyamathi & $-5.42 *$ & $-7.10^{*}$ & -5.42 & $-7.65^{*}$ & -0.21 & -1.59 & 0.46 & $-4.45 * *$ \\
\hline RCBG-1 x Gulabi & $-5.14 *$ & $-8.29 * *$ & 0.00 & -2.35 & $-3.13 * *$ & $-7.46^{* *}$ & 0.70 & $-4.19 * *$ \\
\hline RCBG-1 x Shyamala & -0.64 & $-8.28 * *$ & $-6.63 *$ & $-8.82 * *$ & 1.07 & -0.47 & -1.39 & $-6.18 * *$ \\
\hline RCBG-2 x Bhagyamathi & -3.75 & -5.52 & $-7.23 *$ & $-9.41 * *$ & 1.93 & 1.81 & $4.18 * *$ & -0.88 \\
\hline RCBG-2 x Gulabi & -1.78 & $-8.29 * *$ & 0.00 & -2.35 & 0.44 & $-2.56^{*}$ & $6.03 * *$ & 0.88 \\
\hline RCBG-2 x Shyamala & $9.33 * *$ & 4.46 & -1.20 & -3.53 & $5.26 * *$ & 2.04 & $4.41 * *$ & -0.66 \\
\hline RCBG-3 x Bhagyamathi & 2.44 & 1.82 & 1.20 & -1.18 & -0.12 & -1.59 & 0.46 & $-4.42 * *$ \\
\hline RCBG-3 x Gulabi & $-5.78^{*}$ & $-9.94 * *$ & -1.81 & -4.12 & $-4.02 * *$ & $-8.32 * *$ & -0.23 & $-5.08 * *$ \\
\hline RCBG-3 x Shyamala & -3.25 & $-9.70 * *$ & $-10.24 * *$ & $-12.35^{* *}$ & -1.07 & $-2.58 *$ & $-3.48 * *$ & $-8.17 * *$ \\
\hline RCBG-4 x Bhagyamathi & -3.95 & -4.82 & -4.82 & $-7.06^{*}$ & $2.82 * *$ & 2.25 & $5.57 * *$ & 0.44 \\
\hline RCBG-4 x Gulabi & $-6.63 *$ & $-10.50 * *$ & -2.41 & -4.71 & 0.44 & -2.13 & $6.50 * *$ & 1.32 \\
\hline RCBG-4 x Shyamala & -4.85 & $-11.45^{* *}$ & $-11.45 * *$ & $-13.53 * *$ & $3.61 * *$ & 0.00 & $3.25^{*}$ & -1.77 \\
\hline RCBG-5 x Bhagyamathi & -5.00 & $-6.75^{*}$ & $-8.43 * *$ & $-10.59 * *$ & $-2.86^{* *}$ & $-3.64 * *$ & -1.62 & $-6.40^{* *}$ \\
\hline RCBG-5 x Gulabi & -1.78 & $-8.29 * *$ & 0.00 & -2.35 & $-4.88 * *$ & $-8.53 * *$ & -0.46 & $-5.30 * *$ \\
\hline RCBG-5 x Shyamala & 0.67 & -3.82 & $-9.04 * *$ & $-11.18 * *$ & -1.06 & $-3.23 *$ & $-2.78^{*}$ & $-7.51 * *$ \\
\hline RCBG-6 x Bhagyamathi & -1.99 & $-8.51 * *$ & 3.61 & 1.18 & $3.86 * *$ & 0.86 & $9.28 * *$ & $3.97 * *$ \\
\hline RCBG-6 x Gulabi & $-6.23 *$ & $-7.98 * *$ & 4.22 & 1.76 & 0.43 & 0.21 & $9.05 * *$ & $3.75 * *$ \\
\hline RCBG-6 x Shyamala & -2.11 & $-13.83 * *$ & -2.41 & -4.71 & $3.97 * *$ & -1.93 & $6.26 * *$ & 1.10 \\
\hline RCBG-7 x Bhagyamathi & 3.98 & 3.66 & 2.41 & 0.00 & 0.57 & 0.45 & $2.55^{*}$ & $-2.43^{*}$ \\
\hline RCBG-7 x Gulabi & -4.93 & $-9.39 * *$ & -1.20 & -3.53 & -0.88 & $-4.05 * *$ & $4.41 * *$ & -0.66 \\
\hline RCBG-7 x Shyamala & -0.33 & $-6.71 *$ & $-7.83 *$ & $-10.00 * *$ & $4.34 * *$ & 1.37 & $3.25^{*}$ & -1.77 \\
\hline
\end{tabular}

** Significant at $1 \%$ level and * Significant at $5 \%$ level

Table 5: Average heterosis (\%), heterobeltiosis (\%) and standard heterosis (\%) for number of fruits per cluster and number of fruits per plant in brinjal

\begin{tabular}{|c|c|c|c|c|c|c|c|c|}
\hline \multirow{3}{*}{ Crosses } & \multicolumn{4}{|c|}{ Number of fruits per cluster } & \multicolumn{4}{|c|}{ Number of fruits per plant } \\
\hline & \multirow[b]{2}{*}{$\begin{array}{c}\text { Average } \\
\text { heterosis }(\%)\end{array}$} & \multirow{2}{*}{\begin{tabular}{|c|} 
Heterobeltiosis \\
$(\%)$
\end{tabular}} & \multicolumn{2}{|c|}{ Standard heterosis (\%) } & \multirow{2}{*}{$\begin{array}{c}\text { Average } \\
\text { heterosis } \\
(\%)\end{array}$} & \multirow[b]{2}{*}{$\begin{array}{c}\text { Heterobeltiosis } \\
(\%)\end{array}$} & \multicolumn{2}{|c|}{ Standard heterosis (\%) } \\
\hline & & & Arka Anand & Mahy Hari & & & Arka Anand & $\begin{array}{l}\text { Mahy } \\
\text { Hari }\end{array}$ \\
\hline RCBG-1 x Bhagyamathi & $15.49^{*}$ & -11.87 & 15.57 & 2.23 & $40.49 * *$ & $29.55 * *$ & $24.43 * *$ & $18.14 * *$ \\
\hline RCBG-1 x Gulabi & -3.80 & $-26.40 * *$ & -4.21 & $-15.26^{*}$ & $27.03 * *$ & $18.74 * *$ & 10.75 & 5.15 \\
\hline RCBG-1 x Shyamala & $75.75^{* *}$ & $42.89 * *$ & -1.40 & -12.78 & $17.57 *$ & 13.01 & -8.36 & $-12.99 *$ \\
\hline RCBG-2 x Bhagyamathi & 1.55 & -9.09 & $19.21 *$ & 5.46 & $31.54 * *$ & $24.52 * *$ & $19.60 * *$ & $13.56^{*}$ \\
\hline RCBG-2 x Gulabi & -3.30 & $-13.15^{*}$ & 13.04 & 0.00 & $28.48 * *$ & $23.33 * *$ & $15.03 *$ & 9.22 \\
\hline RCBG-2 x Shyamala & $33.72 * *$ & -5.28 & -1.82 & -13.15 & $28.12 * *$ & $19.91 * *$ & 2.88 & -2.32 \\
\hline RCBG-3 x Bhagyamathi & 10.79 & $-19.25 * *$ & 5.89 & -6.33 & $23.10 * *$ & 11.59 & 7.19 & 1.77 \\
\hline RCBG-3 x Gulabi & $-17.11 *$ & $-39.44 * *$ & $-21.18 * *$ & $-30.27 * *$ & $17.45^{* *}$ & 7.90 & 0.64 & -4.45 \\
\hline RCBG-3 x Shyamala & 8.42 & -6.78 & $-44.04 * *$ & $-50.50 * *$ & 10.06 & 7.74 & $-15.86^{*}$ & $-20.11 * *$ \\
\hline RCBG-4 x Bhagyamathi & $26.81 * *$ & 3.21 & $35.34 * *$ & $19.73 * *$ & $26.19 * *$ & $23.29 * *$ & $24.14 * *$ & $17.87 * *$ \\
\hline RCBG-4 x Gulabi & 12.74 & -7.97 & $19.78^{*}$ & 5.96 & -3.83 & -7.38 & -6.74 & $-11.45^{*}$ \\
\hline RCBG-4 x Shyamala & -2.79 & $-25.89 * *$ & $-38.99 * *$ & $-46.03 * *$ & $32.55 * *$ & $15.51^{*}$ & $16.31 * *$ & 10.43 \\
\hline RCBG-5 x Bhagyamathi & $-29.48 * *$ & $-51.12 * *$ & $-35.90 * *$ & $-43.30 * *$ & $26.28 * *$ & $19.78 * *$ & $15.04 *$ & 9.23 \\
\hline RCBG-5 x Gulabi & $-42.59 * *$ & $-60.13 * *$ & $-48.11 * *$ & $-54.09 * *$ & $-16.58 * *$ & $-19.77 * *$ & $-25.17 * *$ & $-28.95 * *$ \\
\hline RCBG-5 x Shyamala & 9.42 & 1.39 & $-48.67 * *$ & $-54.59 * *$ & $13.31 *$ & 5.85 & -8.81 & $-13.42^{*}$ \\
\hline RCBG-6 x Bhagyamathi & $-30.25 * *$ & $-45.88 * *$ & $-29.03 * *$ & $-37.22 * *$ & 7.94 & -0.23 & -4.17 & -9.01 \\
\hline RCBG-6 x Gulabi & $-22.99 * *$ & $-40.09 * *$ & $-22.02 * *$ & $-31.02 * *$ & $30.84 * *$ & $22.59 * *$ & $14.34 *$ & 8.56 \\
\hline RCBG-6 x Shyamala & -6.31 & $-25.19 *$ & $-45.86 * *$ & $-52.11 * *$ & -0.28 & -4.38 & $-22.06 * *$ & $-26.00 * *$ \\
\hline RCBG-7 x Bhagyamathi & $-23.98 * *$ & $-46.95 * *$ & $-30.43 * *$ & $-38.46 * *$ & -3.73 & -6.51 & -10.20 & $-14.74 *$ \\
\hline RCBG-7 x Gulabi & $-32.36 * *$ & $-52.69 * *$ & $-38.43 * *$ & $-45.53 * *$ & $25.93 * *$ & $24.06 * *$ & $15.72 *$ & 9.87 \\
\hline RCBG-7 x Shyamala & 4.42 & -4.32 & $-50.35 * *$ & $-56.08 * *$ & $16.39^{*}$ & 6.30 & -3.80 & -8.66 \\
\hline
\end{tabular}

** Significant at $1 \%$ level and * Significant at $5 \%$ level 
Table 6: Average heterosis (\%), heterobeltiosis (\%) and standard heterosis (\%) for number of marketable fruits per plant and fruit length (cm) in brinjal

\begin{tabular}{|c|c|c|c|c|c|c|c|c|}
\hline \multirow{3}{*}{ Crosses } & \multicolumn{4}{|c|}{ Number of marketable fruits per plant } & \multicolumn{4}{|c|}{ Fruit length $(\mathrm{cm})$} \\
\hline & \multirow{2}{*}{$\begin{array}{c}\text { Average } \\
\text { heterosis (\%) }\end{array}$} & \multirow{2}{*}{$\begin{array}{c}\text { Heterobeltiosis } \\
(\%)\end{array}$} & \multicolumn{2}{|c|}{ Standard heterosis (\%) } & \multirow{2}{*}{$\begin{array}{c}\text { Average } \\
\text { heterosis } \\
(\%)\end{array}$} & \multirow{2}{*}{$\begin{array}{c}\text { Heterobeltiosis } \\
(\%)\end{array}$} & \multicolumn{2}{|c|}{ Standard heterosis $(\%)$} \\
\hline & & & $\begin{array}{c}\text { Arka } \\
\text { Anand }\end{array}$ & Mahy Hari & & & Arka Anand & $\begin{array}{l}\text { Mahy } \\
\text { Hari }\end{array}$ \\
\hline RCBG-1 x Bhagyamathi & $55.45 * *$ & $36.38 * *$ & $30.43 * *$ & $24.01 * *$ & -2.61 & $-19.24 * *$ & $-39.84 * *$ & 5.05 \\
\hline RCBG-1 x Gulabi & $38.72 * *$ & $25.55 * *$ & 11.87 & 6.36 & 0.39 & -5.11 & $-20.61 * *$ & $38.61 * *$ \\
\hline RCBG-1 x Shyamala & $16.95^{* *}$ & 11.33 & $-19.64 * *$ & $-23.60 * *$ & $-16.55 * *$ & $-31.51 * *$ & $-48.98 * *$ & $-10.92 *$ \\
\hline RCBG-2 x Bhagyamathi & $35.31 * *$ & $19.93 * *$ & $14.70^{*}$ & 9.05 & 5.28 & -0.21 & $-45.36 * *$ & -4.60 \\
\hline RCBG-2 x Gulabi & $43.06 * *$ & $30.86 * *$ & $16.60 *$ & 10.85 & $-10.93 * *$ & $-26.32 * *$ & $-38.35 * *$ & 7.63 \\
\hline RCBG-2 x Shyamala & $43.32 * *$ & $34.92 * *$ & -0.29 & -5.20 & 0.44 & -5.97 & $-48.51 * *$ & -10.09 \\
\hline RCBG-3 x Bhagyamathi & $20.25 * *$ & 5.60 & 0.99 & -3.98 & 4.62 & -2.45 & $-44.68 * *$ & -3.41 \\
\hline RCBG-3 x Gulabi & $24.75 * *$ & 13.02 & 0.71 & -4.26 & -6.01 & $-21.15 * *$ & $-34.03 * *$ & $15.18 * *$ \\
\hline RCBG-3 x Shyamala & $24.97 * *$ & $18.84 *$ & $-14.03 *$ & $-18.27 * *$ & -7.15 & $-14.46 * *$ & $-51.49 * *$ & $-15.31 * *$ \\
\hline RCBG-4 x Bhagyamathi & $22.71 * *$ & $21.54 * *$ & $16.24 *$ & 10.51 & -0.04 & $-16.58 * *$ & $-38.85^{* *}$ & 6.77 \\
\hline RCBG-4 x Gulabi & 5.01 & 2.37 & -3.96 & -8.69 & $-17.29 * *$ & $-22.42 * *$ & $-35.09 * *$ & $13.34 *$ \\
\hline RCBG-4 x Shyamala & $52.73 * *$ & $29.47 * *$ & $21.47 * *$ & $15.48 *$ & -8.27 & $-24.24 * *$ & $-44.47 * *$ & -3.04 \\
\hline RCBG-5 x Bhagyamathi & $31.76 * *$ & $14.67 *$ & 9.67 & 4.27 & -2.53 & -4.71 & $-51.07 * *$ & $-14.57 * *$ \\
\hline RCBG-5 x Gulabi & -9.69 & $-18.95^{*}$ & $-27.78 * *$ & $-31.34 * *$ & $-13.84 * *$ & $-30.48 * *$ & $-41.83 * *$ & 1.56 \\
\hline RCBG-5 x Shyamala & $27.59 * *$ & $22.55^{*}$ & -13.20 & $-17.47 * *$ & -5.69 & -8.97 & $-53.25 * *$ & $-18.36^{* *}$ \\
\hline RCBG-6 x Bhagyamathi & $15.13^{*}$ & 3.37 & -1.13 & -6.00 & 7.25 & 7.18 & $-47.36^{* *}$ & -8.08 \\
\hline RCBG-6 x Gulabi & $19.22 * *$ & 10.53 & -1.52 & -6.37 & $-16.18 * *$ & $-33.48 * *$ & $-44.35 * *$ & -2.83 \\
\hline RCBG-6 x Shyamala & 7.02 & -0.62 & $-24.36^{* *}$ & $-28.09 * *$ & 0.27 & -1.10 & $-51.42 * *$ & $-15.18 * *$ \\
\hline RCBG-7 x Bhagyamathi & -7.90 & -10.85 & $-14.74 *$ & $-18.94 * *$ & $-14.26 * *$ & $-28.30 * *$ & $-47.71 * *$ & -8.70 \\
\hline RCBG-7 x Gulabi & $31.40 * *$ & $31.11 * *$ & $17.35 *$ & 11.57 & $-22.41 * *$ & $-27.39 * *$ & $-39.25 * *$ & 6.07 \\
\hline RCBG-7 x Shyamala & 14.85 & -0.72 & -11.14 & $-15.52^{*}$ & $-9.50^{*}$ & $-25.10 * *$ & $-45.38 * *$ & -4.64 \\
\hline
\end{tabular}

** Significant at $1 \%$ level and * Significant at $5 \%$ level

Table 7: Average heterosis (\%), heterobeltiosis (\%) and standard heterosis (\%) for fruit width (cm) and average fruit weight (g) in brinjal

\begin{tabular}{|c|c|c|c|c|c|c|c|c|}
\hline \multirow{3}{*}{ Crosses } & \multicolumn{4}{|c|}{ Fruit width $(\mathrm{cm})$} & \multicolumn{4}{|c|}{ Average fruit weight (g) } \\
\hline & \multirow{2}{*}{$\begin{array}{c}\text { Average } \\
\text { heterosis } \\
(\%)\end{array}$} & \multirow{2}{*}{$\begin{array}{c}\text { Heterobeltiosis } \\
(\%)\end{array}$} & \multicolumn{2}{|c|}{ Standard heterosis (\%) } & \multirow{2}{*}{$\begin{array}{c}\text { Average } \\
\text { heterosis } \\
(\%)\end{array}$} & \multirow{2}{*}{$\begin{array}{c}\text { Heterobeltiosis } \\
(\%)\end{array}$} & \multicolumn{2}{|c|}{ Standard heterosis (\%) } \\
\hline & & & Arka Anand & Mahy Hari & & & Arka Anand & $\begin{array}{l}\text { Mahy } \\
\text { Hari }\end{array}$ \\
\hline RCBG-1 x Bhagyamathi & 2.26 & -8.12 & $31.44 * *$ & $-12.87 * *$ & $25.70 * *$ & $24.16 * *$ & $24.16 * *$ & $23.51 * *$ \\
\hline RCBG-1 x Gulabi & -10.33 & $-25.33 * *$ & 6.57 & $-29.20 * *$ & $12.39 * *$ & $10.28 *$ & $10.28^{*}$ & 9.71 \\
\hline RCBG-1 x Shyamala & $-17.76^{* *}$ & $-19.33 * *$ & $15.14^{*}$ & $-23.51 * *$ & $10.88^{*}$ & 8.70 & 8.70 & 8.13 \\
\hline RCBG-2 x Bhagyamathi & $13.43 *$ & 11.92 & $30.80 * *$ & $-13.10 * *$ & $17.58 * *$ & $15.45 * *$ & $12.62 *$ & $12.03 *$ \\
\hline RCBG-2 x Gulabi & 5.27 & -4.59 & 11.51 & $-25.92 * *$ & 1.82 & 0.64 & -3.13 & -3.64 \\
\hline RCBG-2 x Shyamala & -1.29 & -8.63 & $25.43 * *$ & $-16.67 * *$ & $16.57 * *$ & $15.33 * *$ & $10.79 *$ & $10.22 *$ \\
\hline RCBG-3 x Bhagyamathi & 0.84 & -3.09 & $19.55 * *$ & $-20.57 * *$ & $21.75 * *$ & $20.94 * *$ & $19.57 * *$ & $18.94 * *$ \\
\hline RCBG-3 x Gulabi & 4.99 & -7.08 & $14.62 *$ & $-23.85 * *$ & $13.87 * *$ & $12.37 * *$ & $11.09^{*}$ & $10.51 *$ \\
\hline RCBG-3 x Shyamala & -4.75 & -9.58 & $22.13 * *$ & $-17.53 * *$ & $11.20^{*}$ & 9.62 & 8.38 & 7.81 \\
\hline RCBG-4 x Bhagyamathi & 0.27 & -0.99 & 12.63 & $-25.17 * *$ & 1.22 & -0.27 & -2.72 & -3.22 \\
\hline RCBG-4 x Gulabi & 6.22 & -1.40 & 9.34 & $-27.36 * *$ & 8.02 & 7.13 & 3.11 & 2.58 \\
\hline RCBG-4 x Shyamala & -2.06 & $-11.47^{*}$ & $21.54 * *$ & $-19.25 * *$ & $18.80^{* *}$ & $17.94 * *$ & $13.30^{*}$ & $12.71 *$ \\
\hline RCBG-5 x Bhagyamathi & 0.48 & -1.39 & $16.52 *$ & $-22.59 * *$ & $10.61 *$ & 9.56 & 6.87 & 6.31 \\
\hline RCBG-5 x Gulabi & -2.52 & -12.08 & 3.89 & $-30.98 * *$ & -0.24 & -0.53 & -4.26 & -4.76 \\
\hline RCBG-5 x Shyamala & -4.10 & $-10.78^{*}$ & $22.49 * *$ & $-18.62 * *$ & 3.98 & 3.78 & -0.30 & -0.82 \\
\hline RCBG-6 x Bhagyamathi & 1.09 & $-12.63 * *$ & $36.42 * *$ & -9.37 & $-15.18^{* *}$ & $-22.63 * *$ & -8.45 & -8.93 \\
\hline RCBG-6 x Gulabi & -8.78 & $-26.65 * *$ & $14.53^{*}$ & $-23.91 * *$ & -0.14 & -9.45 & 7.14 & 6.58 \\
\hline RCBG-6 x Shyamala & -4.25 & $-10.03 *$ & $40.48 * *$ & -6.67 & 7.31 & -2.78 & $15.03 * *$ & $14.43 * *$ \\
\hline RCBG-7 x Bhagyamathi & -5.12 & $-12.52 *$ & $17.91^{*}$ & $-21.67 * *$ & 3.12 & 2.92 & 0.39 & -0.13 \\
\hline RCBG-7 x Gulabi & 4.29 & $-11.10^{*}$ & $19.81 * *$ & $-20.40 * *$ & $13.22 * *$ & $12.69^{*}$ & 9.50 & 8.93 \\
\hline RCBG-7 x Shyamala & -0.60 & -1.51 & $35.21 * *$ & $-10.17 *$ & $26.67 * *$ & $25.95 * *$ & $22.39 * *$ & $21.75 * *$ \\
\hline
\end{tabular}

** Significant at $1 \%$ level and * Significant at $5 \%$ level

Table 8: Average heterosis (\%), heterobeltiosis (\%) and standard heterosis (\%) for fruit yield per plant $(\mathrm{kg})$ and marketable yield per plant $(\mathrm{kg})$ in brinjal

\begin{tabular}{|c|c|c|c|c|c|c|c|c|}
\hline \multirow{3}{*}{ Crosses } & \multicolumn{4}{|c|}{ Fruit yield per plant $(\mathbf{k g})$} & \multicolumn{4}{|c|}{ Marketable yield per plant (kg) } \\
\hline & \multirow{2}{*}{$\begin{array}{c}\text { Average } \\
\text { heterosis } \\
(\%)\end{array}$} & \multirow{2}{*}{$\begin{array}{c}\text { Heterobeltiosis } \\
(\%)\end{array}$} & \multicolumn{2}{|c|}{ Standard heterosis (\%) } & \multirow{2}{*}{$\begin{array}{c}\text { Average } \\
\text { heterosis } \\
(\%)\end{array}$} & \multirow{2}{*}{$\begin{array}{c}\text { Heterobeltiosis } \\
(\%)\end{array}$} & \multicolumn{2}{|c|}{ Standard heterosis (\%) } \\
\hline & & & $\begin{array}{c}\text { Arka } \\
\text { Anand }\end{array}$ & Mahy Hari & & & Arka Anand & $\begin{array}{c}\text { Mahy } \\
\text { Hari }\end{array}$ \\
\hline RCBG-1 x Bhagyamathi & $64.87 * *$ & $57.67 * *$ & $45.00 * *$ & $30.97 * *$ & $89.17 * *$ & $78.69 * *$ & $53.06 * *$ & $39.05 * *$ \\
\hline RCBG-1 x Gulabi & $32.65 * *$ & $28.17 *$ & 15.36 & 4.19 & $51.77 * *$ & $47.57 * *$ & 18.97 & 8.08 \\
\hline RCBG-1 x Shyamala & $76.79 * *$ & $65.32 * *$ & $38.75 * *$ & $25.32 *$ & $126.80 * *$ & $84.96 * *$ & $40.87 * *$ & $27.98 *$ \\
\hline RCBG-2 x Bhagyamathi & $75.33 * *$ & $68.35 * *$ & $54.82 * *$ & $39.84 * *$ & $93.67 * *$ & $80.75 * *$ & $54.83 * *$ & $40.65 * *$ \\
\hline RCBG-2 x Gulabi & $50.92 * *$ & $46.43 * *$ & $31.79 * *$ & 19.03 & $74.44 * *$ & $67.52 * *$ & $35.06 * *$ & $22.69 *$ \\
\hline
\end{tabular}




\begin{tabular}{|c|c|c|c|c|c|c|c|c|}
\hline RCBG-2 x Shyamala & $54.93 * *$ & $44.30 * *$ & 22.14 & 10.32 & $97.97 * *$ & $63.08 * *$ & 21.05 & 9.96 \\
\hline RCBG-3 x Bhagyamathi & $64.39 * *$ & $46.99 * *$ & $35.18 * *$ & $22.10 *$ & $74.54 * *$ & $54.80 * *$ & $32.60 * *$ & 20.46 \\
\hline RCBG-3 x Gulabi & $30.99 *$ & 18.25 & 6.43 & -3.87 & $45.17 * *$ & $32.26 *$ & 6.63 & -3.13 \\
\hline RCBG-3 x Shyamala & $75.71 * *$ & $75.06 * *$ & $27.86 *$ & 15.48 & $129.69 * *$ & $98.13 * *$ & $31.32 *$ & 19.30 \\
\hline RCBG-4 x Bhagyamathi & -9.52 & -11.46 & -18.57 & $-26.45 *$ & -13.67 & -16.02 & $-28.06^{*}$ & $-34.65 * *$ \\
\hline RCBG-4 x Gulabi & $35.01 * *$ & $33.53 *$ & 20.18 & 8.55 & $56.35 * *$ & $55.98 * *$ & $26.36 *$ & 14.79 \\
\hline RCBG-4 x Shyamala & $88.25 * *$ & $72.21 * *$ & $51.61 * *$ & $36.94 * *$ & $145.95 * *$ & $95.93 * *$ & $58.72 * *$ & $44.19 * *$ \\
\hline RCBG-5 x Bhagyamathi & -3.17 & -7.96 & -15.36 & $-23.55 *$ & -0.43 & -10.00 & -22.91 & $-29.96 * *$ \\
\hline RCBG-5 x Gulabi & $25.83^{*}$ & 20.83 & 8.75 & -1.77 & $46.16 * *$ & $35.79 *$ & 9.48 & -0.55 \\
\hline RCBG-5 x Shyamala & $27.15^{*}$ & 19.61 & -0.89 & -10.48 & $62.94 * *$ & $38.07 *$ & -4.48 & -13.22 \\
\hline RCBG-6 x Bhagyamathi & -16.67 & -22.33 & $-28.57^{*}$ & $-35.48 * *$ & -10.59 & -16.56 & $-28.53 *$ & $-35.07 * *$ \\
\hline RCBG-6 x Gulabi & 12.96 & 6.35 & -4.29 & -13.55 & 4.13 & 0.00 & -19.38 & -26.76 \\
\hline RCBG-6 x Shyamala & $71.66 * *$ & $64.72 * *$ & $30.89 *$ & 18.23 & $118.64 * *$ & $80.10 * *$ & $33.68 * *$ & 21.44 \\
\hline RCBG-7 x Bhagyamathi & -22.08 & $-28.74 *$ & $-34.46 * *$ & $-40.81 * *$ & -20.60 & -28.51 & $-33.76 * *$ & $-44.37 * *$ \\
\hline RCBG-7 x Gulabi & $45.65 * *$ & $34.52 *$ & 21.07 & 9.35 & $66.13 * *$ & $53.75 * *$ & 23.95 & 12.61 \\
\hline RCBG-7 x Shyamala & $91.87 * *$ & $87.82 * *$ & $43.21 * *$ & $29.35 * *$ & $141.93 * *$ & $105.71 * *$ & $41.12 * *$ & $28.20 *$ \\
\hline
\end{tabular}

** Significant at $1 \%$ level and * Significant at $5 \%$ level

Table 9: Average heterosis (\%), heterobeltiosis (\%) and standard heterosis (\%) for fruit yield per hectare (tons) and marketable yield per hectare (tons) in brinjal

\begin{tabular}{|c|c|c|c|c|c|c|c|c|}
\hline \multirow{3}{*}{ Crosses } & \multicolumn{4}{|c|}{ Fruit yield per hectare (tons) } & \multicolumn{4}{|c|}{ Marketable yield per hectare (tons) } \\
\hline & \multirow{2}{*}{$\begin{array}{c}\text { Average } \\
\text { heterosis } \\
(\%)\end{array}$} & \multirow{2}{*}{$\begin{array}{c}\text { Heterobeltiosis } \\
(\%)\end{array}$} & \multicolumn{2}{|c|}{ Standard heterosis (\%) } & \multirow{2}{*}{$\begin{array}{c}\text { Average } \\
\text { heterosis }(\%)\end{array}$} & \multirow{2}{*}{$\begin{array}{c}\text { Heterobeltiosis } \\
(\%)\end{array}$} & \multicolumn{2}{|c|}{ Standard heterosis (\%) } \\
\hline & & & Arka Anand & $\begin{array}{l}\text { Mahy } \\
\text { Hari }\end{array}$ & & & Arka Anand & $\begin{array}{l}\text { Mahy } \\
\text { Hari }\end{array}$ \\
\hline RCBG-1 x Bhagyamathi & $64.88 * *$ & $57.67 * *$ & $45.99 * *$ & $30.96 * *$ & $89.20 * *$ & $78.70 * *$ & $53.07 * *$ & $39.04 * *$ \\
\hline RCBG-1 x Gulabi & $32.64 * *$ & $28.16^{*}$ & 15.36 & 4.18 & $51.78 * *$ & $47.57 * *$ & 18.97 & 8.07 \\
\hline RCBG-1 x Shyamala & $76.79 * *$ & $65.32 * *$ & $38.74 * *$ & $25.31 *$ & $126.84 * *$ & $84.00 * *$ & $40.88 * *$ & $27.97 *$ \\
\hline RCBG-2 x Bhagyamathi & $75.33 * *$ & $68.35 * *$ & $54.81 * *$ & $39.83 * *$ & $93.69 * *$ & $80.77 * *$ & $54.83 * *$ & $40.65^{* *}$ \\
\hline RCBG-2 x Gulabi & $50.91 * *$ & $46.42 * *$ & $31.78 * *$ & 19.02 & $74.45 * *$ & $67.53 * *$ & $35.06 * *$ & $22.69^{*}$ \\
\hline RCBG-2 x Shyamala & $54.93 * *$ & $44.30 * *$ & 22.13 & 10.31 & $97.99 * *$ & $63.09 * *$ & 21.05 & 9.96 \\
\hline RCBG-3 x Bhagyamathi & $64.39 * *$ & $46.99 * *$ & $35.17 * *$ & $22.09 *$ & $74.55 * *$ & $54.81 * *$ & $32.60 * *$ & 20.45 \\
\hline RCBG-3 x Gulabi & $30.99 *$ & 18.24 & 6.42 & -3.88 & $45.17 * *$ & $32.26^{*}$ & 6.63 & -3.14 \\
\hline RCBG-3 x Shyamala & $75.72 * *$ & $75.06 * *$ & $27.85 *$ & 15.48 & $129.71 * *$ & $98.14 * *$ & $31.32 *$ & 19.29 \\
\hline RCBG-4 x Bhagyamathi & -9.53 & -11.46 & -18.58 & $-26.46^{*}$ & -13.67 & -16.01 & $-28.06^{*}$ & $-34.65 * *$ \\
\hline RCBG-4 x Gulabi & $35.00 * *$ & $33.52 *$ & 20.17 & 8.54 & $56.37 * *$ & $56.00 * *$ & $26.36^{*}$ & 14.79 \\
\hline RCBG-4 x Shyamala & $88.26 * *$ & $72.22 * *$ & $51.60 * *$ & $36.93 * *$ & $145.97 * *$ & $95.95 * *$ & $58.73 * *$ & $44.18 * *$ \\
\hline RCBG-5 x Bhagyamathi & -3.16 & -7.96 & -15.36 & $-23.55^{*}$ & -0.42 & -9.99 & -22.90 & $-29.97 * *$ \\
\hline RCBG-5 x Gulabi & $25.82 *$ & 20.82 & 8.74 & -1.78 & $46.17 * *$ & $35.80 *$ & 9.48 & -0.55 \\
\hline RCBG-5 x Shyamala & $27.15^{*}$ & 19.61 & -0.90 & -10.49 & $62.96^{* *}$ & $38.08^{*}$ & -4.47 & -13.23 \\
\hline RCBG-6 x Bhagyamathi & -16.68 & -22.34 & $-28.58 *$ & $-35.49 * *$ & -10.59 & -16.56 & $-28.53 *$ & $-35.08 * *$ \\
\hline RCBG-6 x Gulabi & 12.95 & 6.34 & -4.29 & -13.56 & 4.12 & -0.01 & -19.39 & -26.77 \\
\hline RCBG-6 x Shyamala & $71.65 * *$ & $64.71 * *$ & $30.88^{*}$ & 18.22 & $118.66^{* *}$ & $80.12 * *$ & $33.69 * *$ & 21.44 \\
\hline RCBG-7 x Bhagyamathi & -22.09 & $-28.75^{*}$ & $-34.48 * *$ & $-40.82 * *$ & -20.61 & -28.51 & $-33.77 * *$ & $-44.38 * *$ \\
\hline RCBG-7 x Gulabi & $45.65 * *$ & $34.51^{*}$ & 21.06 & 9.35 & $66.13 * *$ & $53.75^{* *}$ & 23.96 & 12.60 \\
\hline RCBG-7 x Shyamala & $91.87 * *$ & $87.84 * *$ & $43.20 * *$ & $29.35 * *$ & $141.94 * *$ & $105.70 * *$ & $41.13 * *$ & $28.20^{*}$ \\
\hline
\end{tabular}

** Significant at $1 \%$ level and * Significant at $5 \%$ level

Table 10: Average heterosis (\%), heterobeltiosis (\%) and standard heterosis (\%) for ascorbic acid content (mg/100g) and total phenols content $(\mathrm{mg} / 100 \mathrm{~g})$

\begin{tabular}{|c|c|c|c|c|c|c|c|c|}
\hline \multirow{3}{*}{ Crosses } & \multicolumn{4}{|c|}{ Ascorbic acid content (mg/100g) } & \multicolumn{4}{|c|}{ Total phenols content $(\mathrm{mg} / \mathbf{1 0 0 g})$} \\
\hline & \multirow{2}{*}{$\begin{array}{c}\text { Average } \\
\text { heterosis } \\
(\%)\end{array}$} & \multirow{2}{*}{$\begin{array}{c}\text { Heterobeltiosis } \\
(\%)\end{array}$} & \multicolumn{2}{|c|}{ Standard heterosis (\%) } & \multirow{2}{*}{$\begin{array}{c}\text { Average } \\
\text { heterosis } \\
(\%)\end{array}$} & \multirow{2}{*}{$\begin{array}{c}\text { Heterobeltiosis } \\
(\%)\end{array}$} & \multicolumn{2}{|c|}{ Standard heterosis (\%) } \\
\hline & & & Arka Anand & $\begin{array}{l}\text { Mahy } \\
\text { Hari }\end{array}$ & & & Arka Anand & $\begin{array}{l}\text { Mahy } \\
\text { Hari }\end{array}$ \\
\hline RCBG-1 x Bhagyamathi & $35.13 * *$ & $17.15 * *$ & $34.79 * *$ & $20.77 * *$ & $11.49 * *$ & $-8.73 * *$ & $27.83 * *$ & $52.00 * *$ \\
\hline RCBG-1 x Gulabi & $12.23 * *$ & 2.44 & $17.86^{* *}$ & $5.60 * *$ & $20.33 * *$ & $12.23 * *$ & $15.74 * *$ & $37.63 * *$ \\
\hline RCBG-1 x Shyamala & $8.39 * *$ & $-8.81 * *$ & $4.92 *$ & $-6.00 * *$ & $53.74 * *$ & $47.54 * *$ & $43.23 * *$ & $70.31 * *$ \\
\hline RCBG-2 x Bhagyamathi & $26.89 * *$ & $19.05 * *$ & $14.71 * *$ & 2.78 & $27.99 * *$ & $-5.14 * *$ & $32.86 * *$ & $57.98 * *$ \\
\hline RCBG-2 x Gulabi & $28.45 * *$ & $27.53 * *$ & $22.88 * *$ & $10.10 * *$ & $19.54 * *$ & -1.07 & 2.02 & $21.31 * *$ \\
\hline RCBG-2 x Shyamala & $18.18 * *$ & $7.25 * *$ & 3.35 & $-7.41 * *$ & $35.41 * *$ & $14.82 * *$ & $11.47 * *$ & $32.55 * *$ \\
\hline RCBG-3 x Bhagyamathi & $26.58 * *$ & $21.97 * *$ & 3.00 & $-7.72 * *$ & $5.50 * *$ & $-12.32 * *$ & $22.80 * *$ & $46.02 * *$ \\
\hline RCBG-3 x Gulabi & $7.24 * *$ & -2.18 & $-7.09 * *$ & $-16.75 * *$ & $40.84 * *$ & $33.75 * *$ & $37.93 * *$ & $64.02 * *$ \\
\hline RCBG-3 x Shyamala & $11.70 * *$ & $11.53 * *$ & $-12.40 * *$ & $-21.52 * *$ & $16.71 * *$ & $14.11 * *$ & $10.78^{* *}$ & $31.72 * *$ \\
\hline RCBG-4 x Bhagyamathi & $27.30 * *$ & $22.62 * *$ & $11.76^{* *}$ & 0.13 & $27.35 * *$ & $21.61 * *$ & $70.32 * *$ & $102.53 * *$ \\
\hline RCBG-4 x Gulabi & $38.97 * *$ & $36.17 * *$ & $29.33 * *$ & $15.87 * *$ & $48.52 * *$ & $34.35 * *$ & $71.22 * *$ & $103.60 * *$ \\
\hline RCBG-4 x Shyamala & $18.56^{* *}$ & $10.37 * *$ & 0.59 & $-9.88 * *$ & $41.61 * *$ & $24.74 * *$ & $58.97 * *$ & $89.04 * *$ \\
\hline RCBG-5 x Bhagyamathi & $18.76^{* *}$ & $15.44 * *$ & -2.51 & $-12.65 * *$ & $13.14 * *$ & -1.79 & $37.55 * *$ & $63.56 * *$ \\
\hline RCBG-5 x Gulabi & 3.27 & $-5.03 *$ & $-9.79 * *$ & $-19.18 * *$ & $24.47 * *$ & $24.45 * *$ & $28.34 * *$ & $52.61 * *$ \\
\hline RCBG-5 x Shyamala & $28.17 * *$ & $27.22 * *$ & 1.43 & $-9.13 * *$ & $20.32 * *$ & $16.81 * *$ & $20.42 * *$ & $43.19 * *$ \\
\hline
\end{tabular}




\begin{tabular}{|c|c|c|c|c|c|c|c|c|}
\hline RCBG-6 x Bhagyamathi & 3.06 & 0.06 & $-15.50^{* *}$ & $-24.29^{* *}$ & $7.03^{* *}$ & $-6.17^{* *}$ & $31.41^{* *}$ & $56.27^{* *}$ \\
\hline RCBG-6 x Gulabi & $-13.93^{* *}$ & $-20.93^{* *}$ & $-24.90^{* *}$ & $-32.72^{* *}$ & $4.80^{*}$ & 3.62 & $9.33^{* *}$ & $30.01^{* *}$ \\
\hline RCBG-6 x Shyamala & $-7.29^{* *}$ & $-7.86^{* *}$ & $-26.72^{* *}$ & $-34.35^{* *}$ & $13.25^{* *}$ & $8.72^{* *}$ & $14.72^{* *}$ & $36.41^{* *}$ \\
\hline RCBG-7 x Bhagyamathi & $23.00^{* *}$ & $8.92^{* *}$ & $-8.02^{* *}$ & $-17.59^{* *}$ & $21.78^{* *}$ & -2.85 & $36.06^{* *}$ & $61.79^{* *}$ \\
\hline RCBG-7 x Gulabi & 1.88 & $-14.15^{* *}$ & $-18.45^{* *}$ & $-26.94^{* *}$ & $22.02^{* *}$ & $10.36^{* *}$ & $13.81^{* *}$ & $35.33^{* *}$ \\
\hline RCBG-7 x Shyamala & $12.92^{* *}$ & 3.26 & $-18.90^{* *}$ & $-27.34^{* *}$ & $40.06^{* *}$ & $30.20^{* *}$ & $26.40^{* *}$ & $50.30^{* *}$ \\
\hline
\end{tabular}

** Significant at $1 \%$ level and * Significant at $5 \%$ level

\section{References}

1. Ajjappalavara PS, Dharmatti PR. Combining ability studies in brinjal (Solanum melongena L.). Journal of Asian Horticulture 2006;3(1):1-7.

2. Aswani RC, Khandelwal RC. Hybrid vigour in brinjal (Solanum melongena L.). Annals of Agricultural Research 2003;24(4):833-837.

3. Bailey LH, Munson WM. Experiences with eggplants. New York (Cornell), Station Bulletin 1892;49:338-345.

4. Bavage MS, Madalageri MB, Mulge R. Hybrid performance in round fruited brinjal (Solanum melongena L.). The Karnataka Journal of Agricultural Sciences 2005;1(3):95-97.

5. Bavage MS. Heterosis and combining ability in round fruited brinjal (Solanum melongena L.). M. Sc. (Agri.) Thesis, University of Agricultural Sciences, Dharwad 2002, 1-120.

6. Biswas L, Mehta N, Sabeena FA. Hybrid vigour studies in brinjal (Solanum melongena L.). Global journal of Science Frontier Research Agriculture and Veternary 2013;13(9):1-3.

7. Bitzer MJ, Fonesca S, Papathanasiou G, Patterson FL. Coined the term Heterobeltiosis cited by Fonesca \& Patterson 1968.

8. Bulgundi S. Heterosis and combining ability studies in brinjal (Solanum melongena L.). M. Sc. (Agri.) Thesis, University of Agricultural Sciences, Dharwad 2000, 1106.

9. Chowdhury MJ, Ahmad S, Uddin NM, Quamruzzaman AKM, Patwary MMA. Expression of heterosis for productive traits in $\mathrm{F}_{1}$ brinjal (Solanum melongena L.) hybrids. The Agriculturist 2010;8(2):8-13.

10. Das G, Barua NS. Heterosis and combining ability for yield and its components in brinjal. Annals of Agricultural Research 2001;22(3):399-403.

11. Das S, Mandal AB, Hazra P. Study of heterosis in brinjal (Solanum melongena L.) for yield attributing traits. Journal of Crop and Weed 2009;5(2):25-30.

12. Department of Horticulture, Govt. of Telangana. RSS Database, Ministry of Agriculture, Government of Telangana 2020.

13. Dharwad AN, Patil SA, Salimath PM. Heterosis and combining ability analysis for productivity traits in brinjal (Solanum melongena L.). Karnataka Journal of Agricultural Sciences 2011;24(5):622-625.

14. East EM, Hayes. Heterozygosis in evolution and Plant Breeding. USDA Bureau of Plant Industry Bulletin 1912;243:1-58.

15. Fonesca A, Patterson FL. Hybrid vigour in a seven parent diallele cross in common winter wheat (Triticum aestivum L.). Crop Science 1968;8:85.

16. Gharge CP, Ranpise SA, Shinde KG, Bhalekar MN, Nimbalkar CA. Heterosis for yield in brinjal (Solanum melongena L.). National Academy of Agricultural Science 2016;34(2):407-413.
17. Gururaj S, Patil HB, Sathish D, Kavyashree N. Heterosis for vigour and yield in brinjal (Solanum melongena L.). Environment \& Ecology 2016;35(2D):1434-1442.

18. Joshi N, Singh YV, Bhushan KB. Heterosis for different quantitative traits in brinjal. Pantnagar Journal of Research 2008;6(2):266-269.

19. Kanthaswamy V, Natarajan S, Srinivasan K, Ananthalakshmi A. Genetic studies in brinjal (Solanum melongena L.). South Indian Horticulture 2003;51(16):144-148.

20. Kumar R, Kumar R, Kumar A, Bharathi DK. Estimation of heterosis for yield attributing traits and fruit borer incidence in round brinjal (Solanum melongena L.). Advances in Research 2017;11(3):1-9.

21. Kumar SR, Arumugam T, Anandakumar CR, Balakrishnan S, Rajavel DS. Heterosis expression, interrelationship, direct and indirect effects of component characters on yield in intervarietal crosses of eggplant (Solanum melongena L.). African Journal of Biotechnology 2013;12(45):6366-6375.

22. Kumar V, Pathania NK. Heterosis in bacterial wilt resistant lines of brinjal (Solanum melongena L.). Vegetable Science 2004;31(2):158-160.

23. Magar PG, Magar VG, Gaikwad SS. Heterosis studies for yield characters in brinjal (Solanum melongena L.). International Journal of Tropical Agriculture 2016;34(7):2283-2286.

24. Makani AY, Patel AL, Bhatt MM, Patel PC. Heterosis for yield and its contributing attributes in brinjal (Solanum melongena L.). The bio scan 2013.

25. Nalini D, Patil SA, Salimath PM. Heterosis and combining ability analysis for productivity traits in brinjal (Solanum melongena L.). Karnataka Journal of Agricultural Sciences 2011;24(5):622-625.

26. Naresh BV, Dubey AK, Dabbas MR. Studies of standard heterosis for quantitative traits in egg plant (Solanum melongena L.). International Journal of Agricultural Sciences 2016;12(1):38-41.

27. Pachiyappan R, Saravanan K, Kumar R. Heterosis in yield and yield components in eggplant. International Journal of Current Agricultural Sciences 2012;2(6):1719.

28. Pal BP, Singh HB. Studies in hybrid vigour II. Notes on the manifestation of nasunin, an anthocyanin in eggplant peels. Toxicology 1946;148:119-123.

29. Palli R, Wilson D, Sreenivas G. Heterosis for yield and its attributes in brinjal (Solanum melongena L.). Environment \& Ecology 2016;35(2A):650-655.

30. Patel KK, Sarnaik DA. Performance study of long fruited genotypes of brinjal under Raipur conditions. The Orissa Journal of Horticulture 2003;31(1):74-77.

31. Patidar D, Shitap MS, Patel NA. Heterosis studies for fruit yield and its component in long type brinjal (Solanum melongena L.). Electronic Journal of Plant Breeding 2017;8(4):1169-1176. 
32. Prabhu M, Natarajan S, Pugalendhi L. Studies on heterosis and mean performance in brinjal (Solanum melongena L.). Vegetable Science 2005;32(1):86-96.

33. Pramila Kushwaha ML, Singh YP. Studies on Heterosis in brinjal (Solanum melongena L.). International Journal of Current Microbiology and Applied Sciences 2017;6(11):641-651.

34. Praneetha S, Saraswathy T, Veeraragavathatham D, Pugalendhi L. Per Se performance and heterosis for fruit and shoot borer (Leucinodes orbonalis $\mathrm{Gn}$ ) resistance and yield in brinjal (Solanum melongena L.). Electronic Journal of Plant Breeding 2013;4(1):1061-1066.

35. Pratibha Singh YV, Gupta AJ. Heterosis in brinjal (Solanum melongena L.). Progressive Horticulture 2004;36(2):335-338.

36. Raghu B, Suresh J, Geetha A, Saidaiah P, Sudheer Kumar S. Heterosis for grain yield and its component traits in maize (Zea mays L.) J Res. ANGRAU 2012;40(1):83-90.

37. Raghu B, Suresh J, Geetha P, Saidaiah P, Kumar SS. Heterosis for grain yield and its component traits in maize (Zea mays L.). Journal of Research ANGRAU 2012;40(1):83-90.

38. Ramireddy SRKM, Lingiah HB, Reddy PVK, Naresh P, Kuchi VS. Combining ability studies for yield and yield attributing characters in brinjal (Solanum melongena L.). Plant Archives 2011;11(2):849-852.

39. Rani M, Kumar S, Kumar M. Estimation of heterosis for yield and its contributing traits in brinjal (Solanum melongena L.). Journal of Environmental Biology 2018;39:710-718.

40. Rao TKB. Partial sterility in the first generation plants of crosses between wide varieties of common eggplant. Current Science 1934;2:258-286.

41. Rao TKB. Partial sterility in the first generation plants of crosses between wide varieties of common eggplant. Current Science 1934;2:258-286.

42. Reddy EEP, Patel AI. Heterosis studies for yield and yield contributing characters in brinjal (Solanum melongena L.). Scholarly Journal of Agricultural Science 2014;4(2):109-112.

43. Saidaiah P, Satyanarayana E, Sudheer Kumar S. Heterosis for yield and yield component characters in maize (Zea mays L.). Agricultural Science Digest 2008;28:201-208.

44. Saidaiah P, Ramesha MS, Kumar SS, Geetha A. Evaluation of rice hybrids for heterosis of yield and yield attributing traits over locations. Madras Agricultural Journal 2012;99(4/6):202-209.

45. Sao A, Mehta N. Heterosis and inbreeding depression for fruit yield and its components in brinjal (Solanum melongena L.). Vegetable Science 2011;38(1):88-91.

46. Shafeeq A, Madhusudhan K, Hanchinal RR, Vijayakumar AG, Salimath PM. Heterosis in brinjal. Karnataka Journal of Agricultural Sciences 2007;20(1):33-40.

47. Sharma B, Pathania NK, Gautham V. Combining ability studies in brinjal (Solanum melongena L). Himachal Journal of Agricultural Research 2004;30:54-59.

48. Sharma TK, Pant SC, Kumar K, Kurrey VK, Pandey PK, Bairwa PL. Studies on heterosis in brinjal (Solanum melongena L.). International Journal of Bio-resource and Stress Management 2016;7(5):964-969.

49. Sharma VK. Manifestation of heterosis for quantitative traits in bacterial wilt resistant lines of brinjal (Solanum melongena L.). Journal of Hill Agriculture 2010;1(2):193-196.

50. Shull GH. Cited from methods of plant breeding by Hoyes HK, Immes FR and Smith DC. Mc Graw Hill Co. Inc. NewYork 1914, 1955.

51. Singh AK, Pan RS, Rai M, Prasad VSRK. Heterosis for yield and its contributing attributes in brinjal (Solanum melongena L.). Vegetable Science 2004;31(2):146-148.

52. Singh R, Maurya AN. Hybrid vigour in eggplant (Solanum melongena L). Progressive Horticulture 2005;37(1):100-105.

53. Singh S, Krishnakumar S, Katyal SL. Fruit culture in India. Indian Council of Agricultural Research. New Delhi 1963, 412.

54. Suneetha Y, Kathiria KB. Studies on combining ability for yield, quality and physiological characters in late summer brinjal. International Journal of Agricultural Sciences 2006;2(1):193-197.

55. Suneetha $Y$, Kathiria KB, Kathiria PK, Srinivas $T$. Combining ability for yield, quality and physiological characters in summer grown brinjal. Vegetable Science 2005;32(1):41-43.

56. Timmapur HP, Dharmatti PR, Patil RV, Kajjidoni ST, Naik K. Heterosis for yield in brinjal. Karnataka Journal of Agricultural Sciences 2008;21(3):476-478.

57. Triveni D, Saidaiah P, Ravinder Reddy K, Pandravada SR. Study of heterosis for growth and quality traits in tomato (Solanum lycopersicum L.), Plant Archives 2017;17(2):901-906.

58. Vavilov NI. The origin, variation, immunity and breeding of cultivated plants. Chron. Bot 1951;13:1-364.

59. Venkataramani KS. Breeding brinjals (Solanum melongena L.) in Madras. I Hybrid vigour in brinjal. Proceedings of Academic Science Section B 1946;23:262-273. 